\title{
Okul Öncesi Eğitim Kurumlarının Dış Mekan Özellikleri: Eskişehir İli Örneği*
}

\author{
Fatma GENEY, Zeynep ÖZSOY, Döndü Neslihan BAY** \\ Okul Öncesi Eğitim Kurumlarının Dış Mekan Özellikleri: \\ Eskişehir illi Örneği
}

Özet

Araştırmanın amacı, Eskişehir'deki okul öncesi eğitim kurumlarının dış mekan özelliklerini ortaya koymaktır. $\mathrm{Bu}$ amaç doğrultusunda özel ve devlet anaokullarındaki dış mekanlarda kullanılan materyallerin ve bu materyallerin özelliklerinin neler olduğu araştırılmıştır. Araştırmada nitel araştırma yöntemi kullanılmıştır. Bu bağlamda örneklem içerisinde yer alan okulların dış mekan özellikleri betimlenmeye çalışılmıştır. Betimlenme sürecinde nitel araştırma yöntemlerinden yapılandırılmış gözlem yöntemi uygulanmıştır. Eskişehir merkez ilçelerinde bulunan devlet anaokullarının tamamı (20) ve 15 özel anaokulu olmak üzere toplam 35 okul öncesi eğitim kurumu araştırmanın örneklemini oluşturmaktadır. Ayrıca özel anaokulların belirlenmesi en az 50 çocuk mevcudiyetinin olması ölçüt olarak alınmıştır. Araştırma sonucunda mekan büyüklüğü, oyun alanlarının düzenlenmesi ve materyal çeşitliliği yönlerinden her iki okul grubunun da eksikleri olduğu; devlet anaokullarının özel anaokullarına göre daha iyi düzeyde olduğu sonucuna ulaşılmıştır.
Outdoor Properties of Preschool Education Institutions: Sample of Eskisehir

Abstract

The aim of the research is to reveal the outdoor characteristics of pre-school education institutions in Eskisehir. For this purpose, the materials used in private and public kindergartens and their properties are researched. In the research is used qualitative research methods. In this context, the outdoor features of the schools in the sample have been tried to be described. In the describing process, structured observation method is applied from qualitative research methods. A total of 35 pre-school education institutions, including 20 total state kindergartens in Eskişehir, central districts and 15 private kindergartens, forms the sample of the research. In addition, the identification of private kindergartens has been accepted the attendance of at least 50 children in the school. When the results of the research were evaluated, it was concluded that both school groups were deficient in terms of space size, the arrangement of playgrounds and material diversity, it was concluded that state kindergartens were at a better level than private kindergartens.

Anahtar Kelimeler: Anaokulu, Dış Mekan, Bahçe, Materyal.

Key Words: Preschool, Outdoor, Garden, Material.

\section{Giriş}

Günümüzde sanayileşme, nüfus artışı, köyden kente göçler vb. nedenlerle betonlaşma ve çarpık kentleşme ortaya çıkmaktadır. Kentsel mekanlarda açık alanlar, çocukların gözlemleyebilecekleri yeşil alanlar, doğal göletler, kent ormanları, çalılıkların ve ağaçların bulunduğu alanlar, bitkilerin ve hayvanların bulunduğu toprak alanlar, geniş kum alanları,

*Bu çalışma 13.Okul Öncesi Eğitimi Öğrenci Kongresinde sözlü bildiri olarak sunulmuştur.

** Fatma GENEY, geneyyfatma@outlook.com, ORCID ID orcid.org / 0000-0002-4480-4364, Zeynep ÖZSOY, zynpozsoy26@outlook.com, ORCID ID orcid.org / 0000-0001-9108-565X, Döndü Neslihan BAY, Dr. Öğr. Üyesi, Eskişehir Osmangazi Üniversitesi, Eğitim Fakültesi, bayneslihan@gmail.com, ORCID ID orcid.org / 0000-0002-2656-0458 
küçük taşlıkların bulunduğu alanlar gibi doğal/açık alanlar yavaş yavaş eksilerek yok olmakta, bunun sonucunda da çocuk oyunun dışında kalmaktadır (Çelik, 2012).

Çocuklar sürekli hareket etme ihtiyacı içerisindedirler ve onların sağlıklı gelişimleri için oyun oynamaya ihtiyaçları vardır (Öztürk ve Bayrak, 2017). Doğal öğrenme ortamlarında koşma, atlama, tırmanma ve su, toprak ve kumla oynama gibi etkinlikler çocuğun yeteneklerinin farkına varmasını sağlamakta ve fiziksel gelişimlerini desteklemektedir (Francis, 1998; Marcus ve Francis, 1998). Bu nedenle çocukların yeni şeyler keşfetmelerini ve oyunlar oynamalarını sağlayan açık alanlar oldukça önemlidir. Özellikle havaların ısınmış olduğu bahar ve yaz dönemlerinde açık alanların önemi daha çok dikkat çekmektedir (Öztürk ve Bayrak, 2017; Çelik, 2012).

Açık alanlar çocukların hareket ve oyun ihtiyaçlarını karşılayarak aynı zamanda fiziksel, ruhsal, zihinsel ve sosyal açılardan sağlıklı gelişimlerini etkilemektedir. Bu etkiler şöyle sıralanabilir:

- Dış mekanlar çocukların, özgürce hareket edebilmelerine, yaratıcı düşünmelerine, hayal dünyalarını zenginleştirmelerine, problem çözmelerine, sosyalleşmelerine katkı sağlamaktadır (Özkubat, 2013).

- Çocuklar kentleşme sonucu yapay mekanlar ile çevrelerini keşfedememektedirler. Oysaki dış mekanlar ile çocuklar doğayla iç içe ve doğaya karşı duyarlı olmaktadır (Kaçan Halmatov ve Kartaltepe, 2017). Doğa ile çocuklar duyularını (dokunma, koklama, işitme, görme, duyma) harekete geçirebilirler (Karataç, 2016; Kartal, 2016; Kocabaş, 2016).

- Açık alanlarda, bahçelerde bulunan bitkiler ile çocuklar, bitkilerin renginin değiştiğini, tohumların oluştuğunu ve çimlenmeyi fark eder. Böylece çocuklarda merak duygusu ortaya çıkar ve bu durum çocukların sebep sonuç ilişkisi kurmalarına olanak tanır.

- Çocuklar bitki ve hayvan isimlerini öğrenmesi ile onların keşfetme, gözlem yapma, araştırma gibi yetenekleri gelişir. Çocuklar, bitkiler ve hayvanlar ile çevreye karşı duyarlı olur, canlıları severler (Öztürk ve Bayrak, 2017).

- Dış mekan ile çocuklar kendilerini ifade edebilmeyi öğrenmektedirler. Kendilerine güven duyarak karar verme ve organizasyon becerilerini geliştirirler.

- Dış mekan ile çocuklar birbirleriyle işbirliği içerisinde oyun oynarlar. Dış mekan, çocukların sosyal ve duygusal gelişimlerini destekler.

- Dış mekanda oynanan oyunların çocuklar üzerinde araştırma, risk alma, psikomotor beceriler gibi alanlarda etkileri vardır (Kalburan, 2014).

Okul öncesi eğitim kurumları verdiği eğitimle 36-66 ay dönemindeki çocukların tüm gelişim alanlarını, sağlıklı çevresel koşullarla ve uzman eğitimcilerle destekleyerek, çocukların sosyalleşmesini ve doğru kişilik geliştirmelerini amaçlamaktadır. Bu nedenle okul öncesi eğitim kurumunun dış mekan ve donanımı, çocukların gelişimleri yönünden en az iç mekan kadar önemlidir. Bu bağlamda okulun çevresi, ev benzeri tasarım özelliklerinin eğitimsel tasarım unsurları ile iç içe geçtiği bir mekan olarak tanımlanmaktadır. İç tasarım- 
la uyumlu olarak, okulun dış tasarımının biçim, materyaller, manzara ve mekan olarak çocukları hoş karşılayan bir girişe sahip olması gerekmektedir (Karaküçük, 2008; Çelik, 2012).

Okul öncesi eğitim kurumlarının dış mekan özellikleri deyince çocuğun özgürce oyun oynayabileceği alanlar akla gelmektedir. Bu nedenle okul öncesi kurumlarının dış mekan özelliklerinin bazı niteliklere sahip olmalıdır. Bahçenin büyüklüğü, yapılandırılmış (tahterevalli, salıncak, kaydırak, tırmanma merdiveni vb.), yarı yapılandırılmış (el arabası, oyun evi, bisiklet, kum havuzu, araba lastikleri vb.) ve yapılandırılmamış (su, toprak vb. doğal materyaller) materyallerin çeşitliliği, metrekareye düşen çocuk sayısı, bahçe zemininin özellikleri (toprak, beton, çim, asfalt) okul öncesi eğitim kurumlarının dış mekanlarının sahip olması gereken niteliklerindendir (Çelik, 2012). Dolayısıyla nitelikli okullarda önemli olan unsurlar suyun bulundurulması, çocukların kendi oyun aktivitelerini seçmeleri ve kendi oyun alanlarını oluşturma olasılıkları, doğaya erişim (ağaçlar, göletler, çalılar, çiçekler, uzun çimler, böcekler ve hayvanlar), oynamak için alanlar, oturmak, yaslanmak veya saklanmak için yerler ve çocukların oynayabileceği esnek materyaller de dahil olmak üzere yapılandırılmamış ve manipüle edilebilir bir ortamdır (White ve Stoecklin 1998; Fjortoft ve Sageie 2000; Malone ve Tranter, 2003; Ömeroğlu, 2005). Ayrıca okulların dış mekanları bitkilerin yanı sıra çocukların hayvanları da tanıdığı alanlar olarak görülmelidir. Bu nedenle okulların bahçelerinde kedi, köpek, tavşan gibi hayvanları ve bu hayvanların yaşam alanı olan kulübe, yuva, kafes gibi alanların oluşturulması önerilebilir (Francis, 1998).

Dış mekân çocukların gelişimlerini desteklemesi açısından son derece önemliyken çoğu zaman okul öncesi kurumları tarafından göz ardı edilmektedir. Dış mekân düzenine iç mekânlarda özen gösterildiği gibi özen gösterilmemekte, dış mekâna sadece çocukların oyun oynayabilecekleri geniş alan gözüyle bakılmaktadır. Dış mekânlarda bulunan araçgereç ve materyaller çoğu zaman yetersiz, bazen de çocukların sağlığı açısından tehdit oluşturabilmektedir (Çelik, 2012).

Dış mekan düzenlenirken etkinlik açısından dikkat edilmesi gereken bazı hususlar aşağıda yer almaktadır.

- Dış mekanın büyüklüğü çocukların özgürce hareket edebilecekleri şekilde olmalıdır. Her çocuk için en az 3 metrekare alan bulunmalıdır (Karaküçük, 2008). Ömeroğlu'na (2005) göre ise çocuk başına düşen alan en az 6.5 metrekare olmalıdır.

- Oyun alanlarının yerleştirilmesi çocukların etkinliklere katılımı dikkate alınarak düzenlenmelidir. Aktif alanlar (hareketli oyun alanı) ile pasif alanların (fen eğitimi alanı, kum havuzu, sanat ve okuma yazma alanı) birbirlerini dengeleyecek şekilde yerleştirilmesi önemlidir. Örneğin oyun alanında bulunan kaydırak, salıncak, tahterevalli, tırmanma merdiveni gibi hareketli alanlar bir arada bulunmalı; çocukların daha çok arkadaşlarıyla iletişim kurabileceği, kum havuzu, fen eğitimi alanı, sanat alanı okuma-yazma alanı gibi sessiz alanlar bir arada bulunmalıdır (Ummanel, 2017).

- Dış mekanda bulunan üstü kapalı alanlar, Türkçe dil etkinlikleri, sanat etkinlikleri gibi etkinliklerde kullanım amacına uygun olmalıdır. Öğretmen sadece sınıf içerisinde bu 
etkinliklere zaman ayırmamalı, kapalı alanlarda da etkinlikleri gerçekleştirmelidir (Bay, 2016).

- Oyun alanları hem bireysel etkinliklere hem de grup etkinliklerine yer verecek şekilde olmalıdır. Sanat etkinliği, oyun etkinliği, fen etkinliği, Türkçe dil etkinliği gibi hem bireysel etkinlik hem de grup etkinliği, çocukların yaparak yaşayarak öğrenmelerine fırsat tanıyacak şekilde planlanmalıdır.

- Çocukların suya ulaşabilir olmaları hem etkinlikler için hem de bahçede çocuklar tarafından yetiştirilen bitkilerin bakımı için çok önemlidir. Çocuk, oyunları içerisinde su ile toprağı, kumu ıslatabilmeli; ıslanan kumdaki farklılıkları gözlemleyebilmeli; suda yüzen ve batan nesneleri keşfedebilmelidir (Ummanel, 2017).

Dış mekan düzenlenirken materyal açısından dikkat edilmesi gereken bazı hususlar aşağıda yer almaktadır.

- Oyun alanlarındaki oyun araçlarının bulunduğu yerler iyi düzenlenmiş olmalıdır. Çocuklar hangi alanlarda oynayabileceklerini ayırt etmeli, araç gereçler birbirleriyle iç içe geçmiş/karışık şekilde olmamalıdır. Sınıflardaki öğrenme merkezleri gibi oyun alanları da sınırları belli olacak şekilde planlanmalıdır. Örneğin, oyun alanındaki kaydırak diğer alanların sınırları içerisine girmemelidir (Gül, 2012).

- Materyal çeşitliliği çocuk sayısına uygun olmalı; çocukların bireysel etkinlikler yapmalarına, birbirleriyle iletişim kurmalarına, paylaşımda ve işbirliğinde bulunmalarına elverişli olmalıdır.

- Materyaller çocukların tüm gelişim alanlarını destekleyecek nitelikte olmalıdır. Fiziksel açıdan, çocukların kaba motor-ince motor gibi fiziksel becerilerini; sosyal-duygusal açıdan, sosyalleşmelerini, arkadaşlarıyla işbirlikçi oyunlar oynamalarını, iletişim becerilerini; bilişsel açıdan ise, problem çözme becerilerini, farklı açılardan düşünme becerilerini, keşfetme becerilerini desteklemelidir (Ummanel, 2017).

- Materyaller çocukların dikkatini çekecek nitelikte olmalıdır. Çocukların hayal dünyalarını harekete geçiren, yaratıcı düşünme becerilerini geliştiren, canlı renklerden oluşan materyallerden oluşmalıdır. Materyaller doğal yaşam (taş, dal, yaprak, odun vb.) ve günlük yaşamdaki çocuğun karşılaşabileceği materyallerden (elek, tırmık, kürek, kova vb.) oluşmalıdır.

Dış mekan düzenlenirken uyarlama açısından dikkat edilmesi gereken bazı hususlar aşağıda yer almaktadır.

- Dış mekan farklı yaş grupları için uygun olmalıdır. 0-3 yaşları arasındaki çocuklar denemeye isteklidirler. Dış mekan çocuklara güvenli bölge sağlamalıdır. Çocukların gelişimlerine, fiziksel özelliklerine uygun çevre oluşturacak şekilde uyarlanmalıdır. 3-5 ve 5-7 yaşları arasındaki çocuklarda ise etkinlik seviyeleri, motor becerilerdeki incelik, düşünme süreçleri vb. şeklinde dış mekandan yararlanmalıdır (Gül, 2012). Dış mekandaki materyaller çocukların kendi yaş gruplarına uygun materyalleri seçecek şekilde uyarlanmalıdır. 
- Dış mekan özel yetersizliği olan çocuklar için de uygun olmalıdır. Özel gereksinimli çocukların aynı sınıf ortamında ve dış mekanda akranlarıyla birlikte eğitim alabilmeli, etkinliklere katılabilmeli, materyallerde uyarlama yapılabilmelidir. Özellikle okul binalarına girişte fiziksel yetersizliği olan öğrenciler için rampalarla desteklenmeli, rampaların yan kısmına mutlaka korkuluk yapılmalıdır. Okul ve sınıf kapıları tekerlekli sandalyelerin geçebileceği genişliğe uygun olmalıdır (Kaymaz, 2015).

Dış mekan düzenlenirken çeşitlilik açısından dikkat edilmesi gereken bazı hususlar aşağıda yer almaktadır.

- Dış mekan arazisi çocukların hareket ihtiyacına uygun olmalıdır. Çocuklar düz araziden çok engebeli arazide vakit geçirmekten keyif alırlar. Dolayısıyla engebeli araziler (tepeler, çukurlar vb.) Çocukların özgün hareket edebilecekleri şekilde tasarlanmalıdır (Ömeroğlu, 2005; Gül, 2012).

- Dış mekan farklı zemin alanlarına sahip olmalıdır. Zemin doğal (toprak, çim, çakıl) ve yapay yüzeylerden (beton ve kauçuk) oluşmalı, zeminin çalılar ve ağaçların olduğu doğal bir düzenlemesi olmalıdır. Bu şekilde farklı zemin özelliklerini tanımalıdır (Güleş ve Erişen, 2013).

- Dış mekan çocukların bitki yaşam döngüsünü gözlemleyebilmeleri için uygun olmalıdır. Bu alanla çocukların bitkileri tanımalarını, sevmelerini, çevreyi korumaya yönelik bilinçli bakış açısı geliştirmelerini sağlamalıdır (Gülay, 2011). Çocuk doğayla iç içe olmalı, kendi yetiştirebileceği bitki alanları bulunmalıdır. Çocuklar bu alanda aktif olarak katılmalı, bitkilerin oluşumlarını gözlemleyebilmelidir. Çocuklar bu şekilde zevk alarak yaptığı işlerde sorumluluk bilincini ve yaşam becerilerini geliştirebilmektedir (Çelik, 2012; Bay, 2016).

- Dış mekan hayvanların doğal yaşam ortamlarını gözlemleyebilmeleri açısından uygun olmalıdır. Bu gözlem sonucunda çocuklar hayvanları tanımalı, onları koruma açısından duyarlılık kazanmalı, hayvan sevgisi ve sorumluluk duygularını da kazanmalıdır (Gülay, 2011). "Doğal" dünya ile olan bu açık bağlantıların yanı sıra, farklı ve iyi tasarlanmış bir oyun ortamı, işbirliği, sahiplenme, aidiyet, saygı ve sorumluluk konularında önemli dersler geliştirmek için bir fırsat sunmaktadır (Johnson 2000, Malone ve Tranter, 2003).

- Dış mekanda kullanılan görsel figürler çocuklar açısından dikkat çekici olmalıdır. Mekan çocuğa hoş ve sevimli bir ortam sağlamalıdır. Renk ve figürler çocuğun dikkatini çekecek şekilde tasarlanmalı ve estetik görünüm kazandırmalıdır (Benliay, Cüce ve Soydan, 2014).

Çocukların gelişimi için önemli olan dış mekan düzenlemesinde ilgili araştırmalara baktığımızda bununla ilgili çok da yeterli olmayan düzenlemelerin olduğu görülmektedir. Kocaeli'nde yapılan araştırmaya göre; anaokullarının bahçesi olmayan okullarda ya da ilkokullara bağlı bahçeyi kullanan okullarda çocuk başına düşen açık alanın 7-14 metrekarenin çok altında olduğu, en az ve en fazla bahçe alanı bulunan okullar arasında 8 kat fark olduğu görülmüştür. Okul bahçelerinde doğal materyallerden çok plastik materyallerin 
Fatma GENEY | Zeynep ÖZSOY | Döndü Neslihan BAY

kullanıldığı, kullanılan materyallerin yetersiz olduğu, mevcut alanların doğadan yalıtılmış olduğu tespit edilmiştir. Araştırmanın sonucunda anaokullarında çocuk başına düşen açık alan miktarlarında büyük farklılıklar gözlenmiş ve herhangi bir standardın olmadığı belirlenmiştir (Çelik, 2012).

Sivas'ta yapılan araştırmaya göre anaokullarında binanın dış görünüşünün uygun olmadığı; okulların güneş almadığı ve çok katlı bina yapılarından oluştuğu gözlenmiştir. Ayrıca bahçe düzenlemesinin çok az olduğu, yıl boyunca yeşil kalabilen bitkilerin ve ağaçların sadece birkaç okulda bulunduğu görülmüştür. Gözlemlenen bir diğer önemli sorun da dış mekanlarda bulunan oyun araçlarının var olmadığıdır (Karaküçük, 2008). Denizli'de yapılan araştırmaya göre; dış mekanların doğal unsurlar bakımından yetersiz olduğu; resmi anaokullarının özel anaokullarına göre zemin bakımından daha çeşitli olduğu; özel anaokullarının ise resmi anaokullarına göre etkinlikleri gerçekleştirme açısından daha yeterli düzeyde olduğu gözlenmiştir. Buna karşılık okul bahçesinde gerçekleştirilen bilişsel alanı destekleyen etkinlikler arasında; matematik çalışmasına ve okuma- yazma çalışmalarına daha az yer verildiği görülmüştür (Kalburan, 2014). Ankara ve Muğla ilinde yapılan araştırmaya göre; incelenen anaokullarının yarısının bahçesinin bulunmadığı; dış mekanda bulunan materyallerin, spor alanının ve yeşil alanların eksik olduğu; açık alanlarının oyun için uygun olmadığı ve etkin kullanılmadığı görülmüştür (Kaçan, Halmatov ve Kartaltepe, 2017). Eskişehir ilinde okul öncesi eğitim kurumlarının dış mekan özellikleri üzerine yapılan herhangi bir araştırmaya rastlanmamıştır.

Yapılan araştırmalarda okulların dış mekanlarının yeterli büyüklükte olmadığı, yeterli düzeyde materyal bulunmadığı, sanat, müzik, gösteri, fen eğitimi, hayvan yetiştirme, bitki yetiştirme ve kum havuzu gibi etkinlik oyun alanlarının yetersiz olduğu ve çocukların öğretmen ve aileleriyle birlikte deney ve gözlem yapacakları alanlara ihtiyaçlar olduğu görülmüştür. (Baran, Yılmaz ve Yıldırım, 2007; Karaküçük, 2008; Özdemir ve Yılmaz, 2008; Atabey, Yurt ve Ömeroğlu, 2009; Çelik, 2012; Kalburan, 2014; Kaçan, Halmatov ve Kartaltepe, 2017). Şehirleşmenin getirmiş olduğu olumsuzlukların giderilmesi için okul ortamlarında dış mekanların iyileştirilmesine yönelik yeterli düzeyde düzenlemelerin yapılmadığı görülmektedir. Bu durum, okul yöneticilerinin ve öğretmenlerin dış mekanın önemine yönelik farkındalıklarının arttırılması gerektiğini göstermektedir. Bu bağlamda araştırmada Eskişehir ilindeki mevcut durumun ortaya konulması ve okul öncesi eğitim kurumlarının nitelikli olması yönünde farkındalık oluşturulması hedeflemiştir.

\subsection{Araştırmanın Amacı}

Bu araştırmanın amacı, Eskişehir merkez ilçelerinde yer alan okul öncesi eğitim kurumlarının dış mekan özelliklerini ortaya koymaktır. Bu amaç doğrultusunda aşağıdaki araştırma soruları belirlenmiştir:

1. Özel ve devlet anaokullarının dış mekanlarında hangi materyaller vardır?

2. Özel ve devlet anaokullarında dış mekan özellikleri nasıldır? 


\section{Yöntem}

\subsection{Araştırmanın Yöntemi}

Okul öncesi eğitim kurumlarının dış mekan özelliklerinin neler olduğunu betimlemeyi amaçlayan bu araştırma nitel bir araştırmadır. Nitel araştırma, algıların ve olayların doğal ortamda gerçekçi ve bütüncül bir biçimde ortaya konmasına yönelik bir sürecin izlendiği araştırma olarak tanımlanabilir. Bir başka deyişle; nitel araştırma, kuram oluşturmayı temel alan bir anlayışla sosyal olguları, bağlı bulundukları çevre içerisinde araştırmayı ve anlamayı ön plana alan bir yaklaşımdır (Glaser, 1978; Yıldırım ve Şimşek, 2013). Araştırmada okul öncesi eğitim kurumlarının dış mekan özellikleri doğal ortamı içinde bütüncül olarak ortaya konmaya çalışılmıştır.

Eğitim alanında yaygın kullanılan nitel araştırmalarda veriler; görüşmeler, gözlemler ya da doküman analizi yoluyla toplanır (Merriam, 2013). Araştırmada nitel araştırma yöntemlerinden yapılandırılmış gözlem yöntemi uygulanmıştır. Yapılandırılmış gözlem, gözlenecek durumla ilgili daha iyi bir planlama ve sistematik bir yaklaşım durumlarında kullanılmaktadır (Yıldırım ve Şimşek, 2013). Araştırma kapsamında “Okul öncesi eğitim kurumlarındaki dış mekan gözlem formu" oluşturulmuş ve form uygulanarak araştırmacılar tarafından kodlama yapılmıştır.

\section{2. Çalışma Grubu}

Eskişehir ili Odunpazarı ve Tepebaşı merkez ilçelerinde bulunan devlet anaokullarının tamamı (20) anaokulu da araştırma kapsamına alınmıştır. Araştırmada özel anaokullarının belirlenmesinde amaçlı örneklem yöntemlerinden ölçüt örneklem yöntemi kullanılmıştır. Ölçüt örneklem, bir araştırmada gözlem birimleri belli niteliklere sahip kişiler, olaylar, nesneler ya da durumlardan oluşmaktadır. Bu durumda örneklem için belirlenen ölçütü karşılayan birimler örnekleme alınırlar (Yıldırım ve Şimşek, 2013). Araştırmada ölçüt örneklem yöntemine göre Eskişehir ili, Odunpazarı ve Tepebaşı merkez ilçelerdeki en az 50 öğrenci çocuk mevcudiyeti bulunan, 15 özel anaokulu araştırma kapsamına alınmıştır. Aşağıda devlet ve özel anaokullarının harita üzerinde dağılımları verilmiştir. 


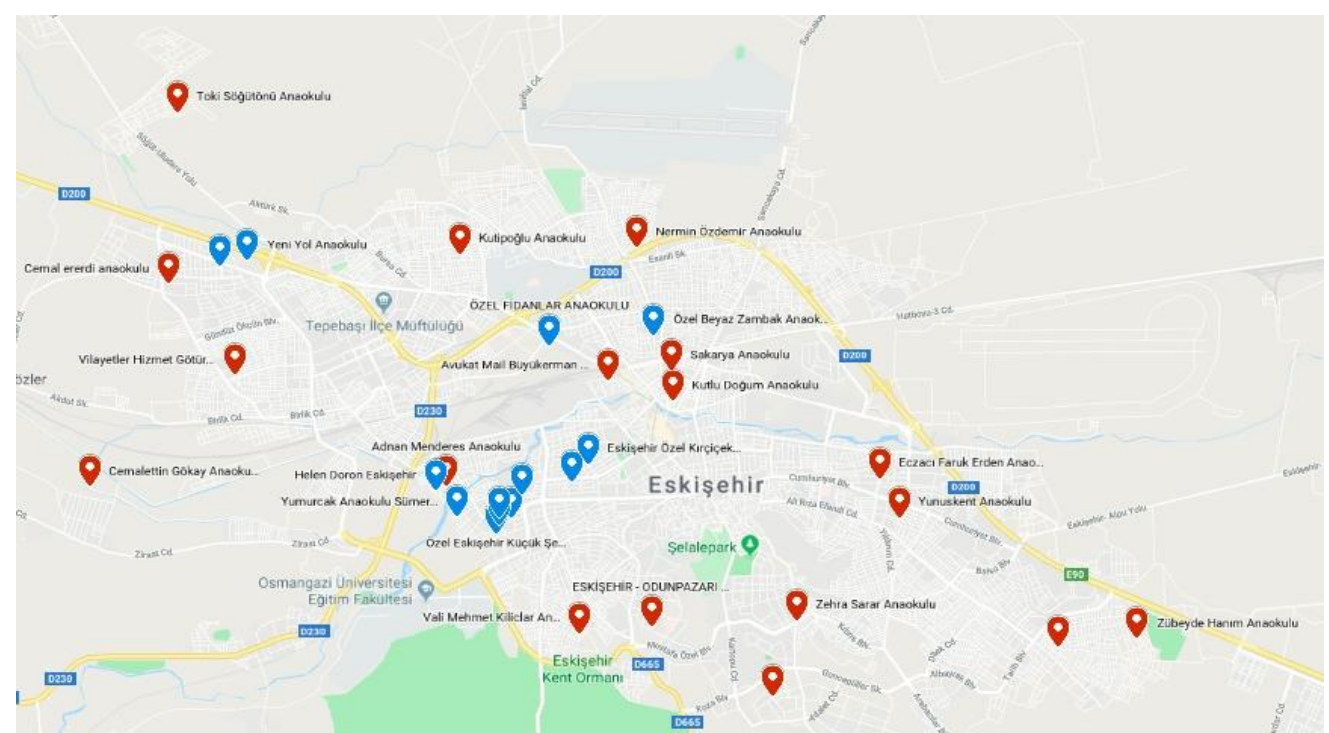

Şekil 1. Eskişehir'de Devlet ve Özel Anaokullarının Dağılımı (Kırmızı-devlet anaokulu, maviözel anaokulu)

Devlet ve Özel anaokulları olmak üzere toplamda 35 okul öncesi eğitim kurumu araştırma kapsamına alınmıştır. Araştırmaya katılan okulların listesi Ek'te verilmiştir.

\subsection{Verilerin Toplanması}

Bu araştırmada elde edilen veriler 20 devlet ve 15 özel anaokulu ziyaret edilerek toplanmıştır. Anaokullarındaki müdür veya müdür yardımcılarıyla görüşülmüş, araştırmanın amacı hakkında bilgilendirilme yapılarak dış mekanlar fotoğraflanmıştır.

Araştırmacılar tarafından "okul öncesi eğitim kurumlarının dış mekan materyalleri kontrol listesi" ve "okul öncesi eğitim kurumlarındaki dış mekan gözlem formu" oluşturulmuştur. Araştırmada kontrol listesi ve gözlem formunun oluşturulma sürecinde ilgili literatür incelenmiş ve araştırma soruları doğrultusunda gözlem boyutları belirlenerek kodlama listesi oluşturulmuştur. Elde edilen verilerin betimlenmesinde gözlemcilerin yapılandırılmamış notları ve fotoğraf görüntüleri kullanılmıştır.

Kontrol listesi dört ayrı alan altında sınıflandırılmış ve her bir madde "var-yok" olarak kodlanmıştır. Kontrol listesi esnek tutulmuş, var olan bütün materyaller kodlamaya alınmıştır. Gözlem formu “okul öncesi eğitim kurumlarının dış mekan özellikleri” adı altında dört alandan oluşmaktadır. Bu alanlar, altı maddeden oluşan etkinlik alanı; dört madden oluşan materyal alanı; iki maddeden oluşan uyarlama alanı ve beş maddeden oluşan çeşitlilik alanıdır. Veriler okul ziyaretlerinde her bir okulun dış mekanlarında fotoğraflar çekilerek ve gözlem formu kodlanarak toplanmıştır. 


\subsection{Verilerin Analizi}

Araştırmacılar tarafından doğrudan yapılan gözlem sonrası kodlama yapılan kontrol listesi ve gözlem formu kodlarına fotoğraflar detaylı olarak tekrar gözden geçirilerek son hali verilmiş ve her bir madde üzerinden yüzde frekanslar belirlenmiştir. Gözlem formu ile toplanan veriler betimsel analiz ile çözümlenmiştir. Betimsel analiz, verilerin görüşme ve gözlem sürecinde oluşturulan boyutlar dikkate alınarak yorumlanmasıdır (Yıldırım ve Şimşek, 2016). Bu araştırmada da gözlem formundan belirlenen boyutlar doğrultusunda yüzde-frekanslar üzerinden veriler yorumlanmıştır.

\subsection{Geçerlilik ve Güvenirlik}

Bu araştırmada geçerliğin sağlanabilmesi için araştırmanın amacı doğrultusunda araştırma alanında doğrudan doğal ortam içinde yansız gözlem yapılmıştır. Araştırmanın güvenirliği için gözlem yolu ile elde edilen veriler doğrudan sunulmalıdır (Yıldırım ve Şimşek, 2016). Araştırmada okullardan elde edilen görsel dokümanlardan örnekler, bulgular kısmında doğrudan verilmiştir.

Nitel araştırmalarda geçerlik ve güvenirlik için elde edilen gözlem formuna yönelik uzman görüşü alınabilir, bulgular görüşme yoluyla teyit edilebilir ve bulgular üzerinde araştırmacılar arasında uzlaşma sağlama yoluna gidilebilir (Yıldırım ve Şimşek, 2016). Araştırmada oluşturulan gözlem formunun dış mekanın özelliklerini ölçmede yeterli ve anlaşılır olup olmadığına yönelik üç uzmandan görüş alınmış ve gözlem formu düzenlenmiştir. Araştırmada elde edilen veriler okul yöneticileri ile görüşülerek teyit edilmiş ve okul öncesi eğitim kurumlarının dış mekan özellikleri bir çok açıdan fotoğraf çekimi yapılarak kaydedilmiştir. Araştırmacıların kodlamalarının güvenirliği, Güvenirlik= Görüş Birliği/ Görüş Birliği + Görüş Ayrılığı x 100 formülü (Miles ve Huberman, 1994) kullanılarak hesaplanmıştır. Buna göre araştırmanın kodlayıcı güvenirliği \% 92 olarak hesaplanmıştır. Araştırmacılar tarafından yapılan kodlamalar karşılaştırılarak uzlaşma sağlanmış ve tek bir kodlama sonucuna ulaşılmıştır.

\section{Bulgular}

Okul öncesi eğitim kurumlarındaki özel ve devlet anaokulların da yapılan gözlemler sonucunda elde edilen bulgular araştırma soruları doğrultusunda düzenlenmiştir. Doküman haline getirilen veriler ilgili literatürde yer alan boyutlar altında gruplandırılmış ve yüzde frekans tablosu olarak verilmiştir.

\section{1. Özel ve Devlet Anaokullarının Dış Mekanlarında Bulunan Materyaller}

İlgili araştırma sorusu doğrultusunda yapılan gözlemlerde hangi materyallerin var olup olmadığına yönelik kontrol listeleri sonuçları aşağıdaki tabloda verilmiştir. \%50'nin üzerinde ve \%10'un altında olan değerler sarı ile belirtilmiştir. 
Fatma GENEY | Zeynep ÖZSOY | Döndü Neslihan BAY

Tablo 1. Okul Öncesi Eğitim Kurumlarının Dış Mekan Materyalleri

\begin{tabular}{|c|c|c|c|c|}
\hline \multirow{2}{*}{$\begin{array}{l}\text { Kategori } \\
\text { Oyun Alanı }\end{array}$} & \multicolumn{2}{|c|}{ Özel Anaokulu (n=15) } & \multicolumn{2}{|c|}{ Devlet Anaokulu $(n=20)$} \\
\hline & $f$ & $\%$ & $f$ & $\%$ \\
\hline Kaydırak & 14 & 93 & 17 & 85 \\
\hline Salıncak & 12 & 80 & 17 & 85 \\
\hline Tahterevalli & 2 & 13 & 16 & 80 \\
\hline Tırmanma merdiveni & 5 & 33 & 11 & 55 \\
\hline Kum havuzu & 4 & 27 & 11 & 55 \\
\hline \multicolumn{5}{|c|}{ Fen- Matematik Eğitim Alanı } \\
\hline Bitki yetiştirme & 3 & 20 & 9 & 45 \\
\hline Deney-gözlem & 1 & 7 & 3 & 15 \\
\hline Hayvan yetiştirme & 1 & 7 & 6 & 30 \\
\hline \multicolumn{5}{|l|}{ Hayvanlar } \\
\hline Kedi & 1 & 7 & 1 & 5 \\
\hline Köpek & 0 & 0 & 1 & 5 \\
\hline Tavuk & 1 & 7 & 3 & 15 \\
\hline Ördek & 0 & 0 & 1 & 5 \\
\hline \multicolumn{5}{|c|}{ Yazma Alanı } \\
\hline Tebeşir & 0 & 0 & 4 & 20 \\
\hline Resim tahtası & 0 & 0 & 4 & 20 \\
\hline \multicolumn{5}{|c|}{ Genel Görünüm } \\
\hline Üstü kapalı alan & 1 & 7 & 8 & 40 \\
\hline Duvarlarda renk kullanımı & 9 & 60 & 16 & 80 \\
\hline Figür & 8 & 53 & 14 & 70 \\
\hline
\end{tabular}

Tablo 1'de görüldüğü gibi okulların dış mekanda bulunan materyallerinin neler olduğuna dair yapılan gözlem sonrasında kontrol listesi, oyun alanı, fen-matematik eğitimi alanı, hayvan besleme alanı, yazma alanları ve genel görünüm sınıflandırmaları altında oluşmuştur. Sınıflandırmalar arasında oyun alanı materyallerinin hem özel anaokullarında hem de devlet anaokullarında diğer materyallere oranla daha fazla yer aldığı görülmüştür. Bir diğer önemli sonuç ise deney-gözlem alanı ve yazma alanındaki materyallerin diğer materyallere oranla daha az miktarda bulunmasıdır. Okullar genel görünüm açısından değerlendirildiğinde renk ve figür kullanım oranlarının \% 50'nin üzerinde olduğu görülmektedir. Genel olarak okullarda var olan materyaller değerlendirildiğinde müzik, drama, dil ve sanat gibi eğitim alanlarına yönelik materyallerin bulunmadığı görülmüştür.

Eğitim kurumlarında oyun alanı materyal gözlemi sonucunda kaydırak, salıncak, tahterevalli, tırmanma merdiveni ve kum havuzu materyalleri ile karşılaşılmıştır. Aşağıda materyallerden örnek fotoğraflar verilmiş ve devlet-özel okullar açısından değerlendirilmiştir. 


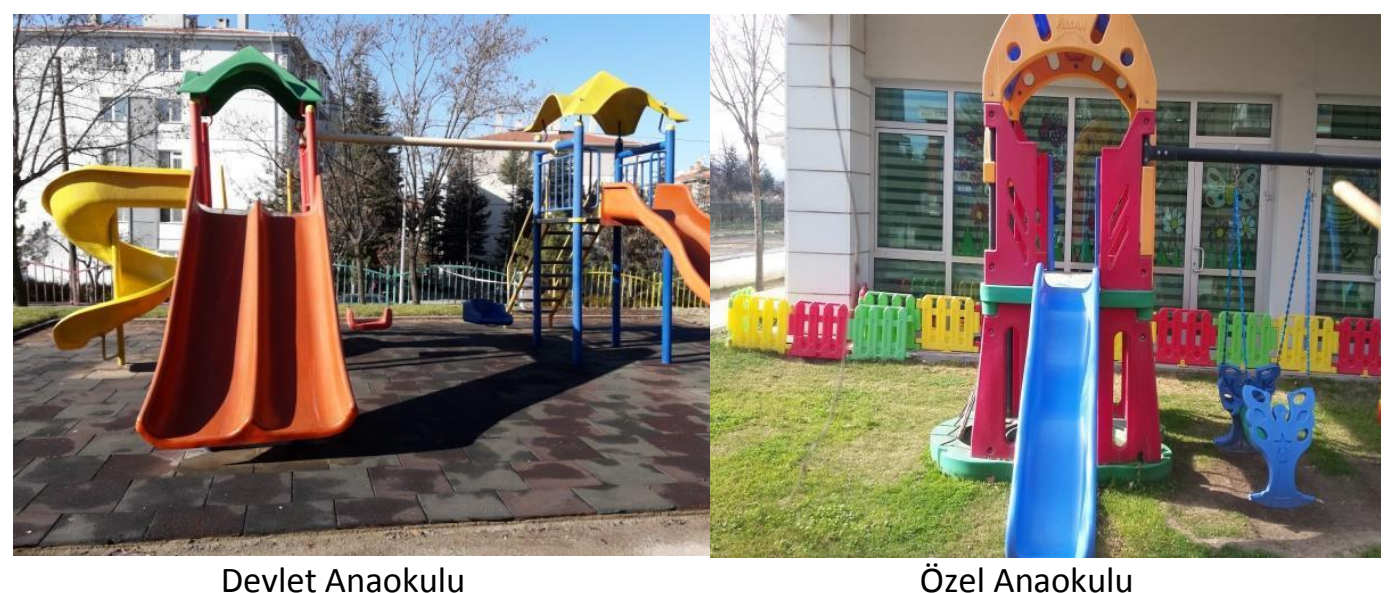

Resim 1. Kaydırak

Araştırmada elde edilen bulgulara göre; özel anaokulları ve devlet anaokullarında kaydırak birinci sırada yer almaktadır. Dolayısıyla kaydırağın en fazla tercih edilen materyal olduğu görülmüştür. Hem özel (\%93) hem de devlet anaokullarında (\%85) kaydırağa yüksek oranda yer verildiği belirlenmiştir. Renkli plastik malzemeden yapılan bu kaydırakların büyüklükleri ve sayıları bahçenin büyüklüğüne göre okullar arasında değişebilmektedir.

Kaydırağa göre daha az karşılaşılan materyalin salıncak olduğu gözlenmiştir. Mevcut materyaller arasında özel anaokulunda \%80 devlet anaokullarında ise \%85 var olduğu tespit edilen salıncağın diğer materyallere oranla daha yüksek oranda olduğu ve ikinci sırada yer aldığı belirlenmiştir. Salıncakların güvenli olduğu, renkli plastik malzemeden yapıldığı ve bazılarının kaydırakla aynı yapı üzerinde yer aldığı görülmüştür. Tahterevallinin bulunma oranına bakıldığında devlet anaokullarında üçüncü sırada (\%80) görülürken, özel anaokulunda beşinci sırayı alarak daha düşük oranda (\%13) yer aldığı gözlenmiştir.

Kum havuzu 15 özel anaokulundan sadece 4 tanesinde (\%27) bulunurken, 20 devlet anaokulunun 11 tanesinde (\%55) yer aldığı görülmüştür. Genel olarak kum havuzlarının Resim 2'de görüldüğü gibi özel anaokullarında daha küçük olduğu da gözlenmiştir. 


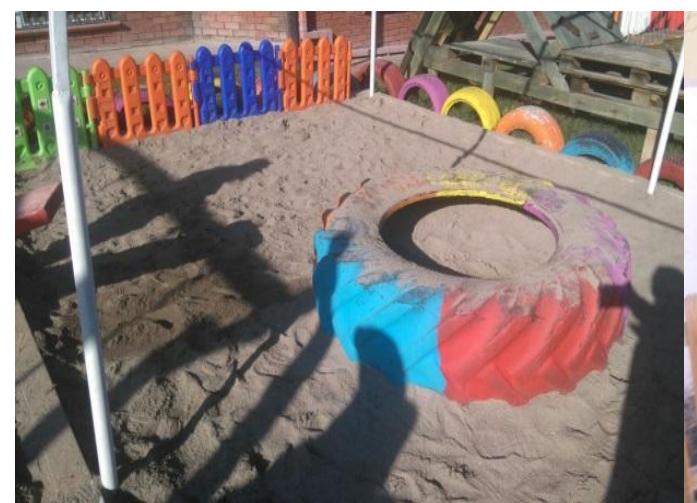

Devlet Anaokulu

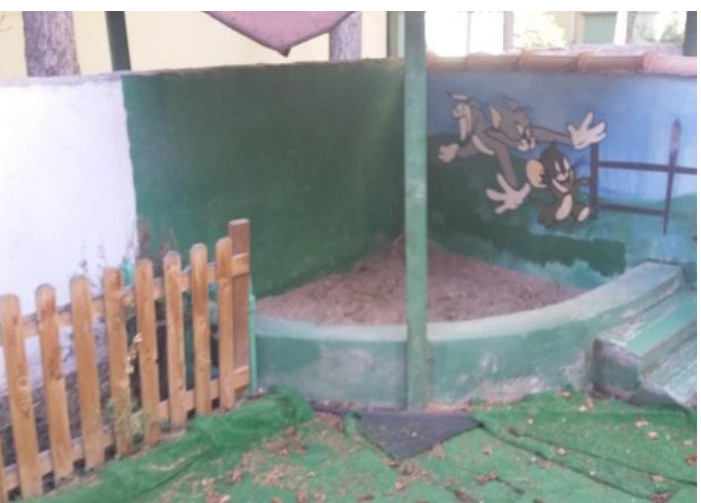

Özel Anaokulu

Resim 2. Kum Havuzu

Kum havuzu ve tırmanma merdivenin devlet anaokulunda eşit oranda (\%55) var olduğu, özel anaokullarında ise tırmanma merdiveninin (\%33) kum havuzuna (\%27) göre daha fazla olduğu tespit edilmiştir. Tırmanma merdivenlerinin ahşap üzerine kalın halatlarla tırmanma ağı şeklinde yapıldığı gözlenmiştir.

Araştırmada fen-matematik eğitim alanı materyalleri bitki yetiştirme alanı, hayvan yetiştirme alanı ve deney-gözlem alanları içinde sınıflandırılmıştır.

Bitki yetiştirme alanının okullarda bulunma oranının \%50'den az olmasının yanı sıra fen-matematik eğitim materyalleri içinde değerlendirildiğinde özel (\%20) ve devlet (\%45) anaokullarının her ikisinde de diğer materyallere oranla daha fazla olduğu gözlenmiştir.

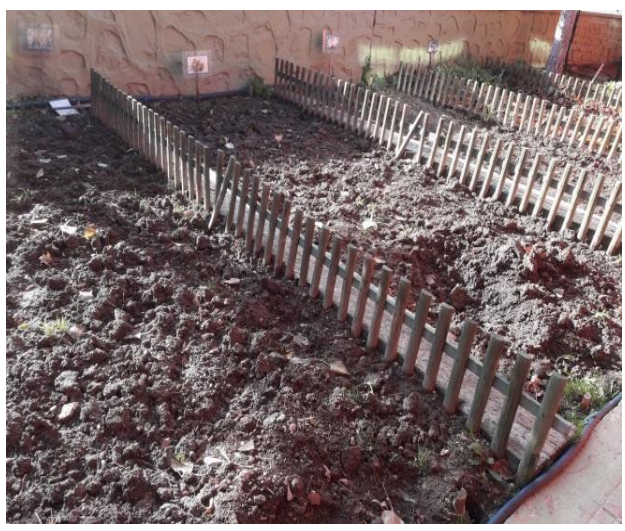

Devlet Anaokulu

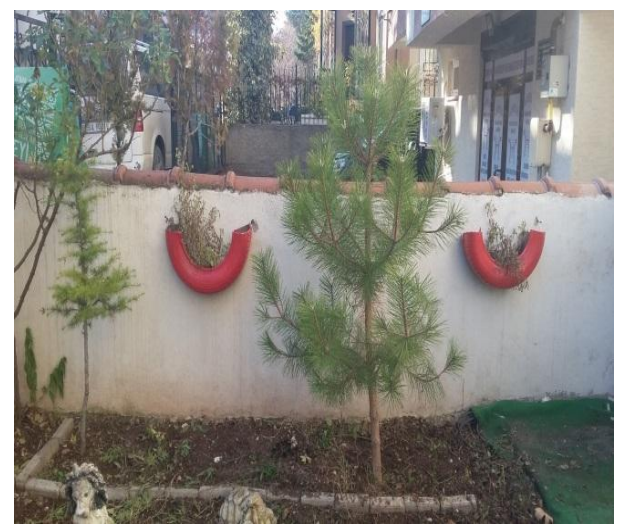

Özel Anaokulu

Resim 3. Bitki Yetiştirme Alanı 
Bitki yetiştirme alanları değerlendirildiğinde okul bahçesinde genel olarak küçük toprak alanlar olarak belirlenmiş ve bazılarında ağaçların dikili olduğu görülmüştür.

Hayvan yetiştirme alanı ve deney-gözlem alanlarının özel anaokulunda eşit oranda (\%7) var olduğu, devlet anaokullarında ise hayvan yetiştirme alanının (\%30) deney gözlem alanına (\%15) göre daha fazla olduğu tespit edilmiştir. Deney gözlem alanında devlet anaokullarında farklı büyüklüklerde ölçme kapları, büyüteçler, çeşitli uzunluktaki çubuklar bulunurken, özel anaokullarında bu materyallere çok az rastlanmıştır. Hayvan yetiştirme alanının sadece bir özel anaokulunda, devlet anaokullarının ise altısında bulunması hayvan yetiştirmenin çok az düzeyde olduğunu göstermektedir.

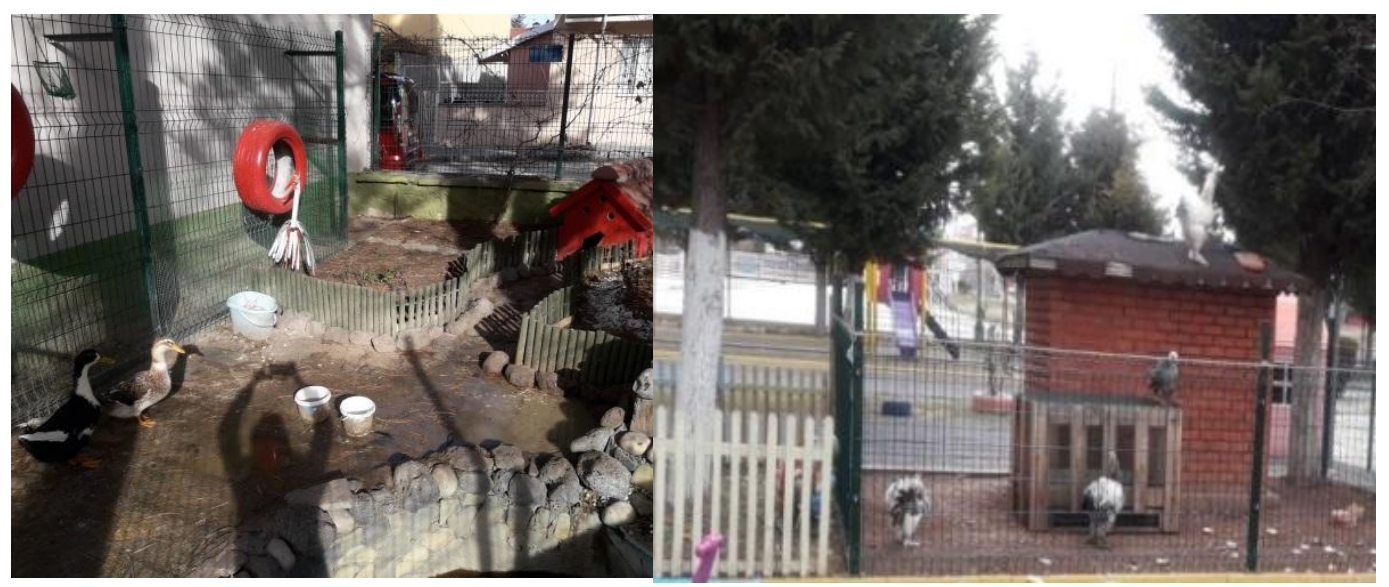

Devlet Anaokulu

Özel Anaokulu

Resim 4. Hayvan Yetiştirme Alanı

Hayvan besleme alanı yüzde olarak değerlendirildiğinde devlet anaokullarında en fazla tavuğun (\%15) olduğu, kedi, köpek ve ördeğin ise eşit yüzdeliğe orana (\%5) sahip olduğu tespit edilmiştir. Kaplumbağa ve tavşan gibi diğer hayvanların ise bulunmadığı gözlenmiştir. 15 özel anaokulundan sadece 2 anaokulunda tavuk ve kedinin (\%7) olduğu görülmüştür. Özel anaokullarında diğer hayvanların hiç yer almadığı tespit edilmiştir.

Yazma alanı olarak materyaller değerlendirildiğinde özel anaokullarında hiç yer almadığı, devlet anaokullarında ise \%20 oranında materyal olduğu gözlenmiştir. Bu materyaller kara tahta, tebeşir, masa, tabure, şeffaf tahta gibi yazma becerisini desteklemeye dönük materyallerdir. 


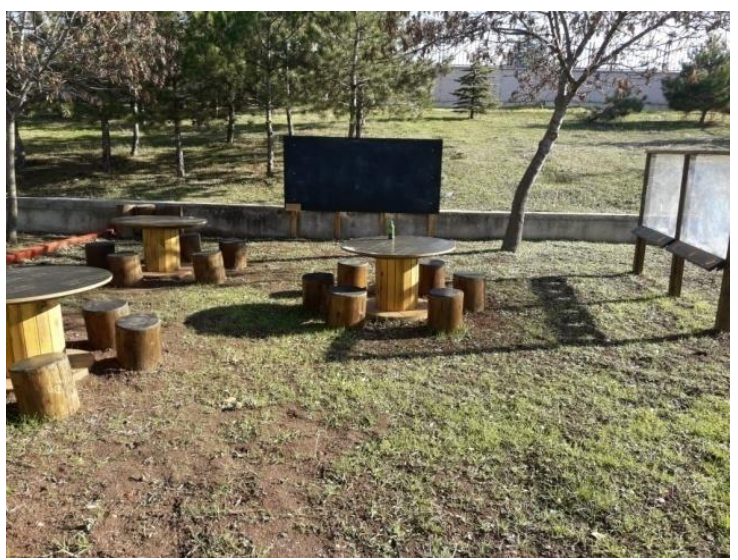

Resim 5. Devlet Anaokulu Yazma Alanı

Okul öncesi eğitim kurumlarının genel görünümü üstü kapalı alan, renk ve figür kategorileri üzerinden sınıflandırımıştır. Üstü kapalı alan olarak okullar incelendiğinde devlet anaokullarının (\%40) özel anaokullarına (\%7) göre daha fazla üstü kapalı alan oluşturduğu gözlenmiştir.

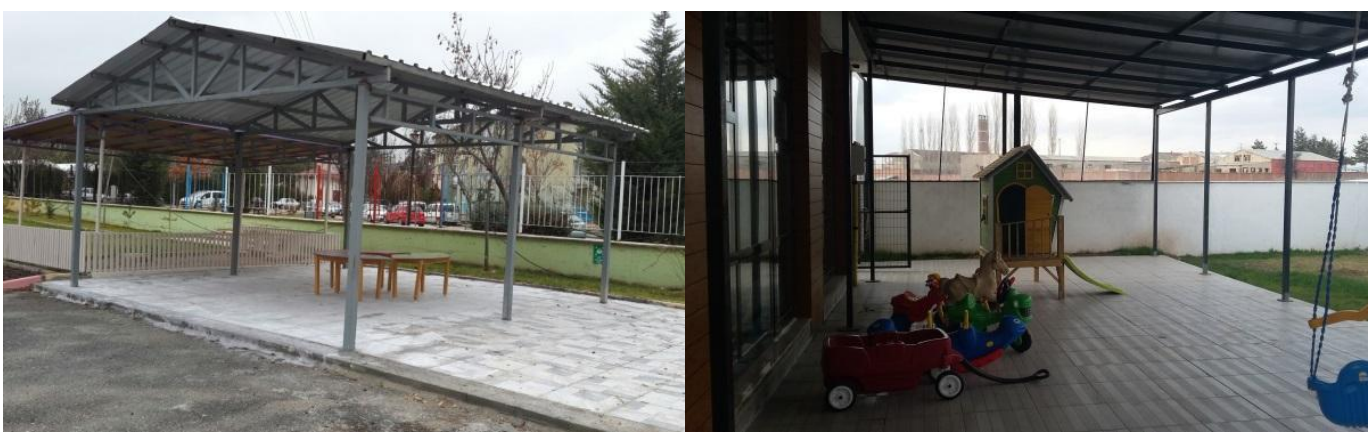

Devlet Anaokulu

Özel Anaokulu

Resim 6. Üstü Kapalı Alan

Resim 6'da da görüldüğü gibi üstü kapalı alanların demir direkler üzerine çatı konarak yapıldığı, altlarının ise beton olduğu tespit edilmiştir. Bu alanların altında masa, plastik oyuncak gibi malzemelerin bulunduğu gözlenmiştir.

Duvarlarda renk ve figür kullanımına bakıldığında özel anaokullarında rengin (\%60), figüre göre (\%53) daha fazla kullanıldığı görülmüştür. Devlet anaokullarında da benzer şekilde renk (\%80), figüre göre (\%70) daha fazla gözlenmiştir. 


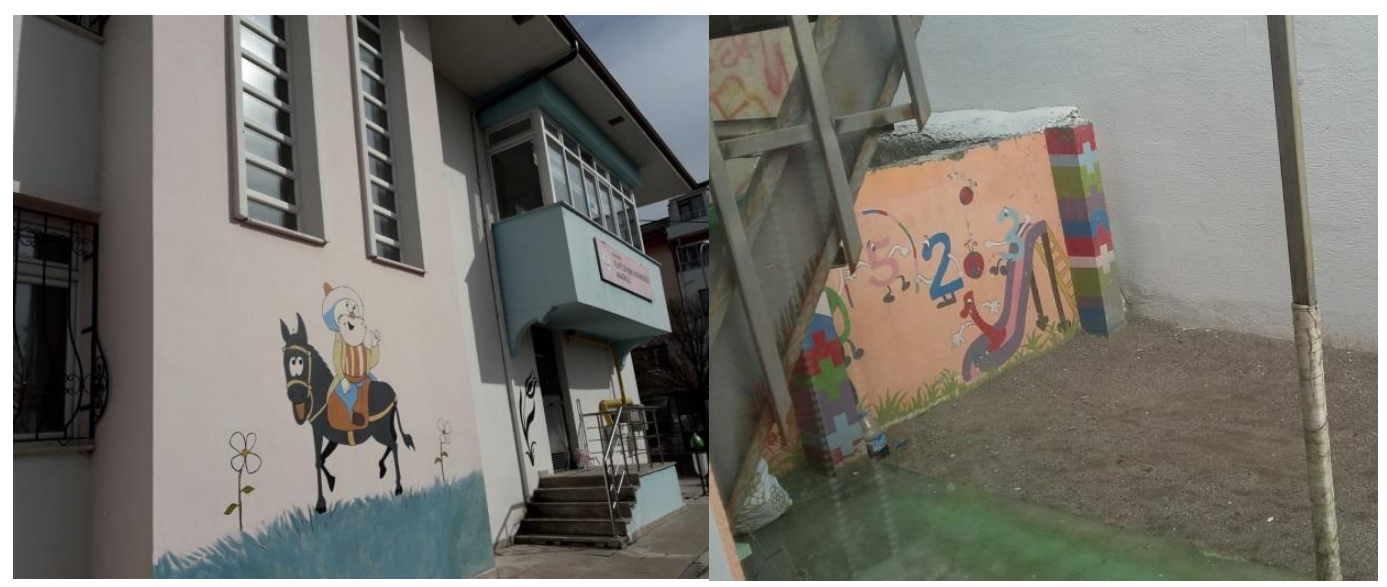

Devlet Anaokulu

Özel Anaokulu

Resim 7. Renk ve Figür

Özel anaokullarının dış mekan resimlerinde renk açısından cansız renklerin kullanıldığı, figür kullanımı açısından ise yetersiz figür olduğu görülmüştür. Özel anaokullarında renk yerine daha çok figürün kullanıldığı ve bu figürlerin de dış mekanda sınırlı alanlarda olduğu gözlenmiştir. Devlet anaokullarında ise canlı renklerin kullanıldığı ve figürlerin birbirleriyle uyum içinde tüm duvarı kapsayacak şekilde olduğu görülmüştür.

\section{2. Özel ve Devlet Anaokulunda Dış Mekan Özellikleri}

Dış mekan özelliklerinin eğitim açısından uygun olup olmadığına etkinlik, materyal, uyarlama ve çeşitlilik boyutları altında 17 madde üzerinden bakılmıştır. Yapılan gözlemler sonucunda elde edilen verilere göre frekans ve yüzde tablosu aşağıda verilmiştir. \%50'nin üzerinde ve $\% 10$ 'un altında olan değerler sarı ile belirtilmiştir. 
Fatma GENEY | Zeynep ÖZSOY | Döndü Neslihan BAY

Tablo 2. Özel Anaokulu ve Devlet Anaokulları Dış Mekan Özellikleri

\begin{tabular}{|c|c|c|c|c|c|c|c|c|c|c|c|c|}
\hline \multirow{3}{*}{$\begin{array}{c}\text { Dış Mekan } \\
\text { Özellikleri } \\
\text { Kategoriler } \\
\\
\text { Etkinlik } \\
\text { Açısından } \\
\end{array}$} & \multicolumn{6}{|c|}{ Devlet Anaokulları $(n=20)$} & \multicolumn{6}{|c|}{ Özel Anaokulları (n=15) } \\
\hline & \multicolumn{2}{|l|}{$\begin{array}{l}\text { Uy- } \\
\text { gun- } \\
\text { Değil }\end{array}$} & \multicolumn{2}{|c|}{$\begin{array}{l}\text { Kısmen } \\
\text { Uygun }\end{array}$} & \multicolumn{2}{|c|}{ Uygun } & \multicolumn{2}{|c|}{$\begin{array}{l}\text { Uygun } \\
\text { Değil }\end{array}$} & \multicolumn{2}{|c|}{$\begin{array}{l}\text { Kısmen } \\
\text { Uygun }\end{array}$} & \multicolumn{2}{|c|}{ Uygun } \\
\hline & $\mathrm{f}$ & $\%$ & $f$ & $\%$ & $f$ & $\%$ & $f$ & $\%$ & $f$ & $\%$ & $f$ & $\%$ \\
\hline $\begin{array}{l}\text { 1. Dış mekanın } \\
\text { büyüklüğü }\end{array}$ & 2 & 10 & 1 & 5 & 17 & 85 & 11 & 74 & 2 & 13 & 2 & 13 \\
\hline $\begin{array}{l}\text { 2. Oyun alanla- } \\
\text { rının yerleşti- } \\
\text { rilmesi }\end{array}$ & 7 & 35 & 3 & 15 & 10 & 50 & 13 & 86 & 1 & 7 & 1 & 7 \\
\hline $\begin{array}{l}\text { 3.Üstü kapalı } \\
\text { alanın kullanımı }\end{array}$ & 12 & 60 & 1 & 5 & 7 & 35 & 13 & 87 & & 0 & 2 & 13 \\
\hline $\begin{array}{l}\text { 4.Bireysel } \\
\text { etkinlik uygu- } \\
\text { lama }\end{array}$ & 7 & 35 & 5 & 25 & 8 & 40 & 9 & 60 & 3 & 20 & 3 & 20 \\
\hline $\begin{array}{l}\text { 5.Grup etkinliği } \\
\text { uygulama }\end{array}$ & 2 & 10 & 5 & 25 & 13 & 65 & 11 & 74 & 2 & 13 & 2 & 13 \\
\hline $\begin{array}{l}\text { 6. Su alanı } \\
\text { kullanımı }\end{array}$ & 17 & 85 & 0 & 0 & 3 & 15 & 15 & 100 & & 0 & & 0 \\
\hline \multicolumn{13}{|l|}{$\begin{array}{l}\text { Materyal } \\
\text { Açısından } \\
\end{array}$} \\
\hline $\begin{array}{l}\text { 7.Materyallerin } \\
\text { konumlandırı- } \\
\text { ması (Aktif- } \\
\text { Pasif) }\end{array}$ & 7 & 35 & 2 & 10 & 11 & 55 & 13 & 86 & 1 & 7 & 1 & 7 \\
\hline $\begin{array}{l}8 . \quad \text { Materyal } \\
\text { çeşitliliğinin } \\
\text { çocuk sayısına } \\
\text { oranı }\end{array}$ & 5 & 25 & 5 & 25 & 10 & 50 & 13 & 86 & 1 & 7 & 1 & 7 \\
\hline $\begin{array}{l}\text { 9. Materyalleri } \\
\text { n farklı gelişim } \\
\text { alanlarının } \\
\text { desteklemesi }\end{array}$ & 6 & 30 & 6 & 30 & 8 & 40 & 13 & 86 & 1 & 7 & 1 & 7 \\
\hline $\begin{array}{l}\text { 10.Materyalleri } \\
\text { n dikkat çekici- } \\
\text { liği }\end{array}$ & 4 & 20 & 5 & 25 & 11 & 55 & 2 & 13 & 7 & 47 & 6 & 40 \\
\hline $\begin{array}{l}\text { Uyarlama } \\
\text { Açısından }\end{array}$ & & & & & & & & & & & & \\
\hline $\begin{array}{l}\text { 11. Farklı yaş } \\
\text { grupları için }\end{array}$ & 5 & 25 & 4 & 20 & 11 & 55 & 13 & 86 & 1 & 7 & 1 & 7 \\
\hline
\end{tabular}


Eskişehir Osmangazi Üniversitesi Sosyal Bilimler Dergisi

\begin{tabular}{|c|c|c|c|c|c|c|c|c|c|c|c|c|}
\hline $\begin{array}{l}\text { 12.Özel gerek- } \\
\text { sinimli çocuklar } \\
\text { için }\end{array}$ & 5 & 25 & 0 & 0 & 15 & 75 & 15 & 100 & & 0 & & 0 \\
\hline \multicolumn{13}{|l|}{$\begin{array}{c}\text { Çeşitlilik } \\
\text { Açısından }\end{array}$} \\
\hline $\begin{array}{l}\text { 13.Çocukların } \\
\text { hareket ihtiya- } \\
\text { cına için (Düz- } \\
\text { Engebeli) }\end{array}$ & 3 & 15 & 5 & 25 & 12 & 60 & 13 & 86 & 1 & 7 & 1 & 7 \\
\hline $\begin{array}{l}\text { 14.Farklı zemin } \\
\text { kullanımı(kum, } \\
\text { çim,çakı,,beton) }\end{array}$ & 4 & 20 & 2 & 10 & 14 & 70 & 7 & 47 & 6 & 40 & 2 & 13 \\
\hline $\begin{array}{l}\text { 15.Bitki yaşam } \\
\text { döngüsünü } \\
\text { gözlemleyebil- } \\
\text { me }\end{array}$ & 11 & 55 & 0 & 0 & 9 & 45 & 12 & 80 & 1 & 7 & 2 & 13 \\
\hline $\begin{array}{l}\text { 16.Doğal yaşam } \\
\text { ortamlarını } \\
\text { gözlemleyebil- } \\
\text { me }\end{array}$ & 15 & 75 & 0 & 0 & 5 & 25 & 13 & 86 & 1 & 7 & 1 & 7 \\
\hline $\begin{array}{l}\text { 17.Kullanılan } \\
\text { görsel figürler }\end{array}$ & 6 & 30 & 5 & 25 & 9 & 45 & 7 & 46 & 4 & 27 & 4 & 27 \\
\hline
\end{tabular}

Tablo 2 incelendiğinde dış mekan özelliklerinin belirlenen alt boyutlar kapsamında devlet anaokullarının uygunluk düzeyinin özel anaokullarına göre daha yüksek düzeyde olduğu görülmektedir. Özel anaokullarında maddelerin tamamı \% 50 uygunluk düzeyinin altında iken devlet anaokullarında 3. 6. 15. 16. maddelerin uygunluğunun \%50'nin altında olduğu belirlenmiştir.

Araştırma doğrultusunda kullanılan gözlem formu etkinlik, materyal, uyarlama ve çeşitlilik açısından gözlemlenmiştir.

\subsubsection{Etkinlik açısından}

Araştırmada elde edilen bulgular, etkinlik açısından; dış mekanın büyüklüğü, oyun alanlarının yerleştirilmesi, üstü kapalı alanın kullanımı, bireysel etkinlik ve grup etkinlikleri uygulama ile su alanı kullanımı alt boyutları şeklinde değerlendirilmiştir. Alt boyutlardan elde edilen sonuçlar incelendiğinde en yüksek oranın (\%85) dış mekan büyüklüğü ile devlet anaokullarında yer aldığı; en düşük oranın ise oyun alanlarının yerleştirilmesi (\%7) ve su alanı kullanımının (\%0) özel anaokullarında yer aldığı görülmüştür. Genel olarak devlet ve özel anaokulu düzeyinde bakıldığında etkinlik alanlarının uygunluklarının devlet anaokullarında daha yüksek düzeyde olduğu tespit edilmiştir.

Devlet anaokullarında dış mekan büyüklüğü \%85 oranında uygun iken, özel anaokullarında dış mekan büyüklüğünün \%13 oranında uygun görülmüştür. 


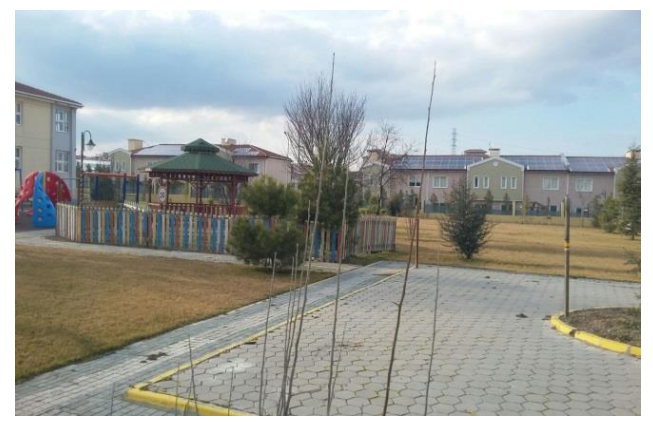

Devlet Anaokulu

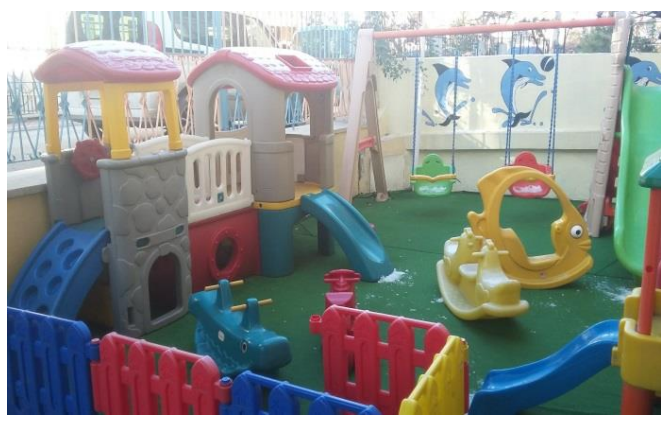

Özel Anaokulu

Resim 8. Dış Mekan Büyüklüğü

Devlet anaokulları bağımsız binalarda daha geniş alanlar üzerinde bulunurken özel anaokullarının çoğunlukla sokak aralarında mevcut binalar içinde yer aldığı belirlenmiştir.

Oyun alanlarının dış mekan üzerinde yerleştirilmelerindeki uygunluk düzeyine bakıldığında devlet anaokullarında \%50 oranında çocukların kullanımına uygun olarak görülürken özel anaokullarında bu oranın \%7 olduğu görülmektedir. Devlet anaokullarında oyun alanları ve materyaller birbirlerinden ayrı ve düzenli şekilde yer alırken, özel anaokullarında oyun materyalleri alanın küçüklüğü nedeni ile birbirleri ile iç içe durumda oldukları gözlenmiştir. Az sayıda bulunan üstü kapalı alanların uygunluk düzeylerine bakıldığında devlet ve özel anaokullarının her ikisinde de uygunluk düzeylerinin \%50’nin altında (\%35, \%13) olduğu görülmektedir.

Dış mekanın büyüklüğü aynı zamanda etkinlik uygulama alanlarında da etkili olmaktadır. Öğretmenler tarafından hareketli oyun gibi büyük grup ya da bireysel etkinlik planlandığında okul dış mekanında uygulama fırsatı veren ortamların uygunluğu değerlendirilmiş; devlet anaokullarında daha uygun alanlar bulunurken özel anaokullarında bu alanların daha sınırlı olduğu gözlenmiştir.

Oyun alanlarının grup etkinliklerine uygunluğuna oran olarak bakıldığında devlet anaokullarının \%65'inin, özel anaokullarının ise \%13'ünün daha uygun olduğu görülmüştür.

Etkinlik alanları boyutunda su kullanım alanları değerlendirildiğinde hem devlet anaokulları hem de özel anaokullarında $(\% 15, \% 0)$ uygun olmayan bir düzenleme olduğu gözlenmiştir.

\subsubsection{Materyal açısından}

Materyaller konumlandırıması, çocuk sayısına oranı, farklı gelişim alanlarını desteklemesi ve dikkat çekiciliği alt boyutlarında uygunlukları yapılan gözlemlerle belirlenmiştir. Devlet anaokullarının materyallerin konumlandırılması ve dikkat çekiciliği alt boyutlarında 
\%50 oranını geçtiği görülmektedir. Özel anaokullarının ise boyutların tamamında \%50’nin altında uygun görülmüştür.

Materyallerin uygun olarak konumlandırıması açısından devlet anaokullarının (\%55) özel anaokullarına (\%7) göre oyun alanlarındaki materyallerin dış mekanda bulunduğu yere göre kullanım uygunluğunun daha fazla olduğu gözlenmiştir.

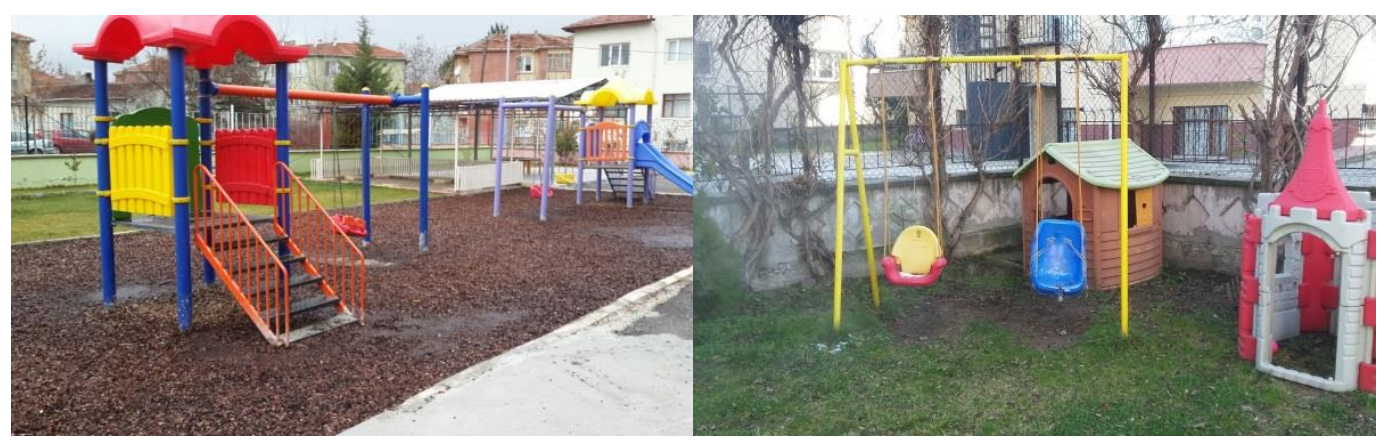

Devlet Anaokulu

Özel Anaokulu

Resim 9. Materyallerin Konumlandırılması

Devlet anaokullarındaki materyallerin birçok çocuğun aynı anda oynamasına imkan sağlayan, sağlam ve çocukların gelişim düzeylerine uygun olduğu gözlenirken, özel anaokullarındaki materyallerin ise daha iç içe geçmiş, çocukların rahat oynamalarına imkan sağlamayan, yaralanmalara neden olabilecek şekilde konumlandırıldığı gözlenmiştir. Materyallerin dikkat çekiciliği açısından incelendiğinde devlet anaokullarının \%55 oranında uygun olduğu görülürken özel anaokullarının kısmen \%47 oranında uygun olduğu görülmüştür. Her iki okulda da oyuncakların, renkli olduğu ve çocuklara yönelik olduğu gözlenmiş ancak devlet anaokullarında daha fazla materyal ile karşılaşıldığı gözlenmiştir.

Materyal çeşitliliğinin çocuklara yeterli oranda bulunması açısından incelendiğinde devlet anaokullarının \%50 oranında uygun olduğu görülürken özel anaokullarında bu uygunluğun \%7 düzeyinde olduğu görülmektedir. 


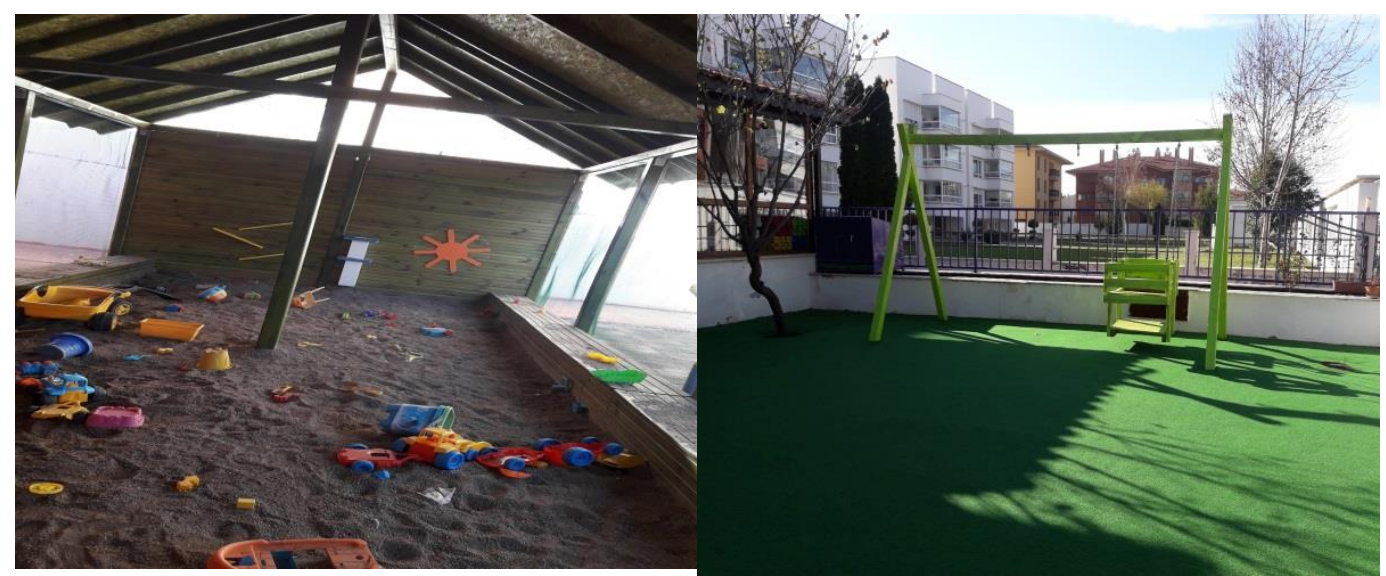

Devlet Anaokulu

Özel Anaokulu

Resim 10. Materyal Çeşitliliği

Farklı amaçlar doğrultusunda kullanılabilecek çeşitli renk ebatlarda materyallerin devlet anaokullarında kullanımının daha uygun düzeyde olduğu görülmüştür. Özel anaokullarında ise çocuklara farklı deneyim fırsatı sağlayacak materyal çeşitliliğinin neredeyse tamamında uygun düzeyde olmadığı tespit edilmiştir.

\subsubsection{Uyarlama açısından}

Uyarlama boyutu altında farklı yaş gruplarına ve özel gereksinimli çocuklar açısından uygunluk düzeylerine bakılmış ve devlet anaokulları \%50'nin üzerinde uygun iken, özel anaokullarında yok denecek kadar düşük düzeyde $(\% 7, \% 0)$ olduğu görülmüştür. 


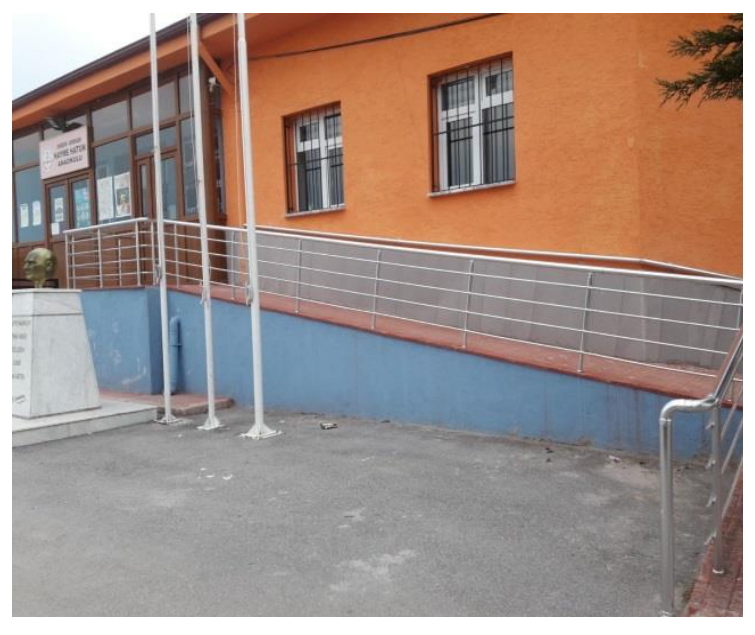

Devlet Anaokulu

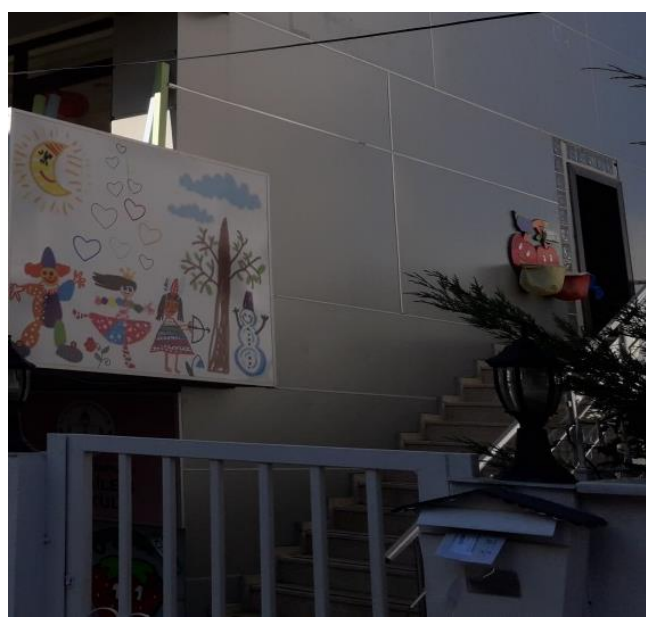

Özel Anaokulu

Resim 11. Uyarlama Açısından

Özellikle özel gereksinimli çocukların okul binalarına rahatlıkla ulaşabilmeleri için devlet anaokullarında rampa ve merdiven asansörlerinin bulunduğu gözlenmiş, özel anaokullarında ise bu tarz uyarlamalara rastlanmamıştır.

\subsection{4. Çeşitlilik açısından}

Çeşitlilik boyutu altında çocukların hareket ihtiyacını karşılama, farklı zemin kullanımı, bitki yaşam döngüsünü gözlemleyebilme, doğal yaşam ortamlarını gözlemleyebilme, kullanılan görsel figürler, alt boyutlarında uygunluk düzeyleri şeklinde belirlenmiştir. Alt boyutlardan hareket ihtiyacı ve farklı zemin kullanımı alt boyutlarında \%50'oranın üzerinde uygunluğu devlet anaokullarında gözlenmiştir. Doğal yaşam ortamlarını gözlemleyebilme alt boyutunda ise \%10'un altında uygun olarak özel anaokulları görülmüştür. Alt boyutların geneline bakıldığında devlet anaokullarının uygunluk düzeylerinin özel anaokullarına göre daha fazla olduğu ortaya çıkmıştır.

Dış mekan çocukların hareket alanı olarak değerlendirildiğinde devlet anaokullarının $\% 60$ düzeyinde özel anaokullarının da \%7 düzeyinde uygun olduğu görülmüştür. Farklı zemin özellikleri değerlendirildiğinde ise devlet anaokullarında farklı zeminlerin \%70 düzeyinde uygun olduğu, özel anaokullarında bu farklılığın kısmen (\%40) uygun olduğu gözlenmiştir. 


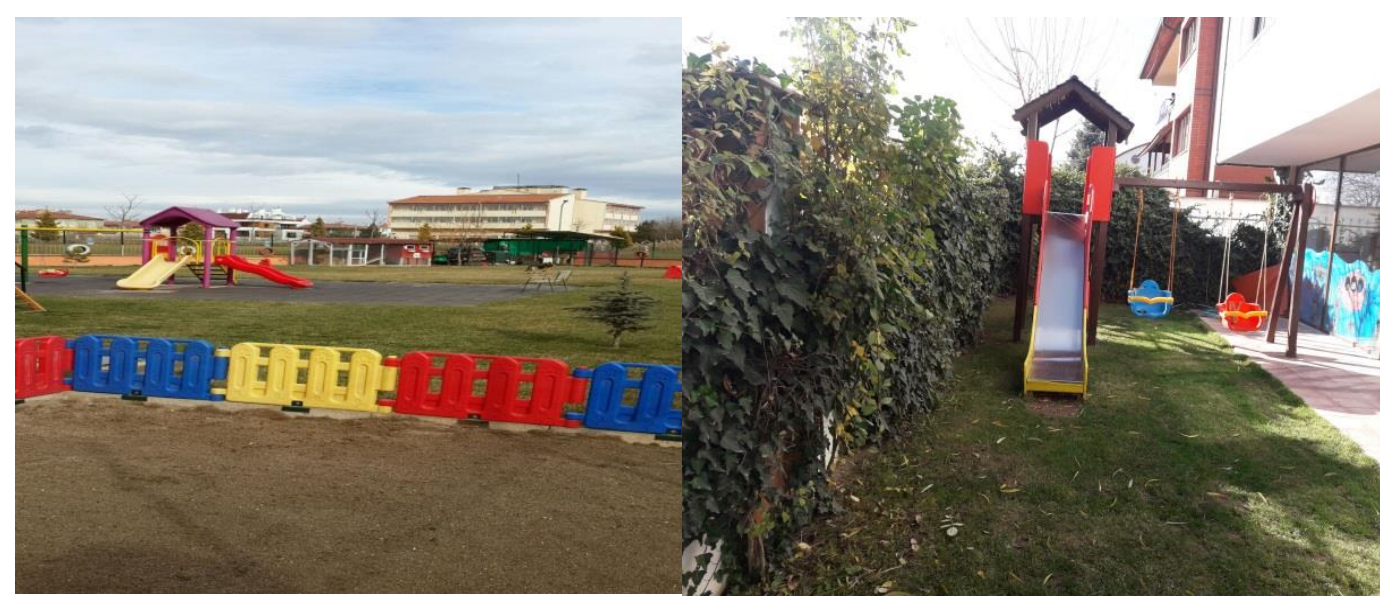

Devlet Anaokulu

Özel Anaokulu

Resim 12. Hareket Alanı ve Farklı Zemin Özellikleri

Resim 12'de de görüldüğü gibi devlet anaokullarının dış mekan alanlarının daha geniş ve rahat hareket alanına sahip olduğu görülürken, özel anaokullarında dış mekanın apartman bahçesi gibi daha dar alanların yapılandırılmasıyla oluşturulduğu gözlenmiştir. Zemin olarak bakıldığında devlet anaokullarında toprak, beton, kauçuk, çimen, kum ve ahşap zeminlerle karşılaşılmış; özel anaokullarında ise daha az zemin farklııklarına (beton ve çim) yer verilmiştir.

Bitki yaşam döngüsü ve doğal yaşam alanlarını gözlemleyebilme alt boyutları incelendiğinde hem devlet hem de özel anaokullarının uygunluk düzeylerinin \%50'nin altında olduğu görülmüştür. Uygunluk düzeyinde en düşük oranın (\%7) doğal yaşam ortamlarını gözlemleyebilme alt boyutu için özel anaokullarında belirlenmiştir. 


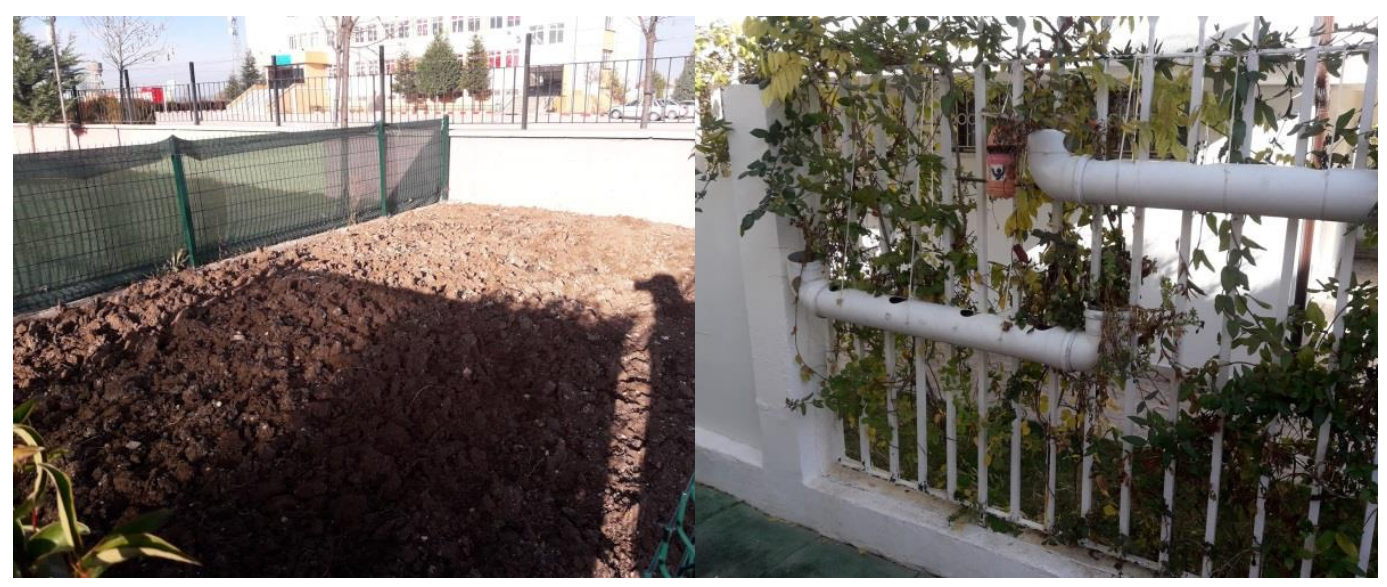

Devlet Anaokulu

Özel Anaokulu

Resim 13. Bitki Yetiştirme Alanı

Bitki yetiştirme alanları devlet anaokullarında çocukların daha rahat hareket etmelerine ve gözlem yapabilmelerine olanak sağlayacak geniş alanlar olarak tasarlanmıştır. Özel anaokullarında ise geniş dış mekan bulunmadığından küçük toprak alanlar veya saksı kullanılarak bitki yetiştirme alanı oluşturulmaya çalışılmıştır.

\section{Tartışma}

Okul öncesi eğitim kurumlarının dış mekan özellikleri, materyaller ve bu materyallerin dış mekanda kullanımlarının uygunluklarını ortaya koymak amacıyla yapılan bu araştırmada elde edilen bulgular ilgili literatür doğrultusunda tartışılmıştır.

Anaokullarının dış mekanlarında hangi materyallerin var olduğuna yönelik yapılan gözlem sonucunda hem devlet hem de özel anaokullarında kaydırak ve salıncak materyallerinin yüksek oranda bulunduğu görülmüştür. Kalburan'ın (2014) Denizli ilinde özel ve devlet anaokullarının bahçelerini karşılaştırmalı olarak incelediği araştırmasında en fazla görülen dış mekan materyallerinin kaydırak ve salıncak olduğu belirlenmiştir. Güleş'in (2013) okul öncesi eğitimde fiziksel çevre standartlarını belirlemek için Konya ilinde yapmış olduğu araştırmasında veli ve öğretmenlere yönlendirilen sorularda en fazla öneme sahip materyallerin çocukların kayma, tırmanma, sallanma, atlama ve denge kurmalarını sağlayabilecek salıncak, kaydırak ve tahterevalli olduğu yönünde cevaplar alınmıştır. Aile ve öğretmenler tarafından önemli görüldüğünü doğrular şekilde yapılan araştırmada da salıncak ve kaydırağın okullarda daha fazla oranda bulunduğu sonucuna ulaşılmıştır. Araştırmada özel anaokullarında tırmanma merdiveninin yanı sıra kum havuzu ve tahterevalli 
materyallerinin de düşük oranda bulunduğu görülmüştür. Bu durum çocukların yeterli düzeyde gelişimlerini destekleme açısından olumsuz olarak değerlendirilmektedir.

MEB Okul Öncesi Eğitim Programında (2013) program kapsamında yapılabilecek etkinliklerin tamamının okulların dış mekanlarında da yapılabileceği ve imkan dahilinde programın esnekliğini kullanarak öğretmenlerin etkinliklerini okul bahçelerinde yapmaları gerektiği belirtilmiştir. Araştırmada anaokullarında gözlemlenen materyaller sadece oyun, fen- matematik ve yazma etkinlik alanlarını destekleme amaçlı olarak belirlenmiştir. Araştırmada her iki okul çeşidinde de sanat, dramatik oyun, Türkçe-dil, müzik etkinlik alanlarında çocukları desteklemeye yönelik materyal bulunmadığı görülmüştür. Kalburan'ın (2014) yapmış olduğu araştırma sonucunda da dış mekanların daha çok oyun amaçIı kullanıldığı, farklı etkinlikler için kullanılmadığı sonucuna ulaşılmıştır. Kaçan, Halmatov ve Kartaltepe'nin (2017) yapmış olduğu araştırmada ise araştırmadaki okulların yarısından fazlasının, dış mekanı etkinliklerde aktif olarak kullanmakta olduğu sonucuna ulaşılmıştır. Bu etkinliklerin başında oyun ve hareket etkinlikleri gelirken sanat, drama, okuma-yazma, fen, matematik, müzik etkinliklerinin de olduğu sonucuna ulaşılmıştır.

Araştırmada renk ve figür kullanımının devlet ve özel anaokullarında yarıdan fazlasında yer aldığı görülmüştür. Benliay, Cüce ve Soydan'ın (2014) okul öncesi eğitim kurumlarında dış mekan peyzaj tasarımının 5-6 yaş çocuklar üzerindeki etkisine yönelik yapmış olduğu araştırmada çocukların sıcak renkli alanlara ve materyallere daha çok ilgi gösterdiği ve bu alanlarda bulunmaktan daha çok zevk aldıkları sonucuna ulaşılmıştır. Bu bağlamda yapılan araştırmada okulların çoğunluğunda renk ve figür kullanımının bulunması olumlu olarak değerlendirilmektedir.

Dış mekan özellikleri açısından bakıldığında 17 madde içinden devlet anaokullarının 10 madde üzerinden $\% 50$ ve üzerinde uygunluğunun bulunduğu, özel anaokullarının ise maddelerin tamamında \%50 oranının altında uygun olduğu görülmüştür. Erken çocukluk döneminde çocuklar zihinsel açıdan gelişmekte olduklarından dolayı çevrelerinden alıcı konumundadırlar. Çukur (2011) göre, çocuklar için oyun temel bir gereksinimdir. Bu yüzden oyun alanları çocuğun doğasına uygun olarak özel bir şekilde tasarlanmalıdır. Ancak bu şekilde zihni ve ruhu sağlıklı çocukların yetişmesi sağlanabilir. Karaküçük'ün (2008) Sivas ilinde yapmış olduğu araştırmada dış mekan düzeninin çocukların ilgi ve gereksinimlerine uygun olmadığı, oyun alanlarının ve dış mekanın genel görünümünün çocuklar açısından uygun olmadığı sonucuna ulaşılmıştır. Ortaya çıkan bu sonuç araştırmadan elde edilen bulguları desteklemektedir.

Araştırmada devlet anaokullarının dış mekanlarının büyüklüğü daha uygun olarak görülürken, özel anaokullarında bu oranın çok daha düşük olduğu görülmektedir. MEB yönetmeliğinde okul bahçelerinin, okul öncesi eğitim düzeyinde çocuk başına $3 \mathrm{~m}^{2}$ olması gerektiğini söylenmektedir. Ayrıca kum havuzu, toprak tepecikler, bisiklet sürme alanı, çakıl, çim ve farklı zemin özelliklerinin olması gerektiği vurgulanmaktadır (Karaküçük, 2008). Araştırmada özel anaokullarının daha çok sokak aralarında ve binaların alt katla- 
rında olması veya müstakil evlerin anaokulu olarak kullanılmasının yetersiz dış mekanlara neden olduğu görülmüştür. Dış mekanın yeterli düzeyde büyük olmaması, dış mekanın etkinlik uygulamalarında da yeterli olup olmamasında doğrudan etkili bir faktördür. Devlet anaokullarında yeterli büyüklükte dış mekan bulunma oranı daha yüksek olduğundan etkinlik uygulama alanlarında uygunluk düzeyi özel anaokullarına oranla daha yüksek düzeyde görülmüştür. Çelik'in (2012) yapmış olduğu araştırmada da okul öncesi eğitim kurumlarında dış mekan özelliklerine yeterince dikkat edilmediği, dış mekanın yeterince büyük olmaması nedeniyle oyun, deney, bitki yetiştirme gibi alanların her okulda bulunmadığı sonucu ortaya çıkmıştır. Bu bağlamda yapılan araştırmada yetersiz dış mekan büyüklüğü özellikle özel anaokullarının uygunluk düzeylerindeki düşüklüğün nedenleri arasında görülmektedir. Atabey, Yurt ve Ömeroğlu (2009) okul öncesi eğitim kurumlarının dış mekanları üzerine Ankara'da yaptıkları çalışmada okulların yetersiz büyüklüğe sahip oldukları sonucuna ulaşmışlardır. Yeterli alan bulunmama sorunu nitelikli dış mekan oluşturulmasında önemli engellerden biridir. Ancak çocukların doğal ortamda en iyi öğrenme alanı olan dış mekanların uygun hale getirilmesinin önemi anlaşılmalıdır (Brynjegard, 2001).

Her iki okul çeşidinde de dış mekanda olması gereken su alanının yetersiz olduğu görülmektedir. Ummanel'in (2017) kum havuzları üzerine yaptığı incelemede kum havuzu oyun alanlarının çocuğun daha özgür hareket edebildiği alanlar olduğunu ve motor becerilerini en üst düzeyde desteklediğin belirtmiştir. Bunun yanı sıra kum havuzu oyun alanlarının çocuğu çevre ile bütünleştiren aktivitelere yönlendirdiğini ve çocuğu su, kum ve çamur gibi malzemeleri keşfederek bir takım yeni deneyimler kazandırdığına değinilmiştir. Bu nedenle araştırmada okullarda yeterli düzeyde olmayan su ve kum oyun alanları, dış mekan yönünden olumsuz olarak değerlendirilmektedir.

Özel gereksinimli çocukların diğer çocuklarla beraber aynı sınıf ortamında ve dış me Özel gereksinimli çocukların diğer çocuklarla beraber aynı sınıf ortamında ve dış mekanda akranlarıyla birlikte eğitim alabilmeleri, etkinliklere katılabilmeleri fiziksel ve duygusal gelişimlerini desteklemek için oldukça önemlidir (Kaymaz, 2015). Araştırmada özel gereksinimli çocuklara yönelik dış mekanlardan elde edilen bulgular incelendiğinde devlet anaokullarının yarıdan fazlasının uygun düzeyine bakıldığında okul girişlerinde rampaların dışında başka bir düzenleme ile karşılaşılmamıştır. Diğerlerinde ise hiçbir düzenleme ile karşılaşılmamıştır. Özel anaokulunda ise özel yetersizliği olan çocuklara yönelik uyarlamanın hiç yapılmadığı görülmüştür. Uslu ve Shakouri (2012), dış mekanda farklı duyulara hitap eden bitki ve oyun alanları (renkli alanlar, sesli alanlar, farklı bitki özellikleri bulunan alanlar vb.) oluşturularak duyusal bahçelerin oluşturulması gerektiğini vurgulamışlardır. Duyusal bahçe içerisinde engelli ve normal çocukların bir arada oynamasını saplayacak yeterli büyüklükteki oyun alanları, görme engellilerin rahat hareket etmesini sağlayacak tabelalar ve engelli çocukların duyularını aktif kullanabileceği koklama ve işitme materyalleri bulunmalıdır. Dış mekanların farklı yaş gruplarına ve özel gereksinimli çocuklara yönelik daha fazla düzenlenmesi gerektiği düşünülmektedir. 
Dış mekanın çocuklara çeşitlilik (hareket, zemin, gözlem) sunması açısından değerlendirildiğinde ise gözlem alanları daha yeterli düzeye getirilmesi gerektiği görülmüştür. Okul öncesin dönem çocuklarının yaşına ve gelişim özelliklerine bağlı olarak ilgi ve gözlem alanları oluşturulmalı, farklı materyal seçimlerine fırsat verilmelidir (Pardee, Gillman ve Larson, 2005; Bay,2016). Karaküçük'ün (2007) Sivas ilinde yapmış olduğu araştırmasında çimenli, çakıl taşlı farklı zemin özellikli alanlar, bisiklete binilecek alanlar, kum havuzu, ağaçlar, toprak tepecikler ve olabilirse açık hava tiyatrosu, küçük evler, bitki bahçeleri, hayvan besleme yerleri, havuz, depo vb. ekler oluşturulması önerilmektedir. Bu araştırmada devlet anaokulunda farklı zemin kullanımı ve düz engebeli alanların yüzdelerinin yüksek olduğu görülmüştür. Kalburan'ın (2014) Denizli ilinde yapmış olduğu araştırmada da devlet anaokullarının dış mekanlarında daha fazla farklı zemin(çim, kum, asfalt, yapay çim, beton) özelliklerine rastlanmıştır.

Var olan materyallerin kullanımın uygunluk düzeylerine bakıldığında devlet anaokullarında ortalama \%50 oranında uygunluk görülürken materyallerin dikkat çekiciliği dışında diğer özelliklerinin özel anaokullarında uygun düzeyde olmadığı görülmüştür. Benzer şekilde Çelik'in (2012) yapmış olduğu araştırmada dış mekanın çocukların hareket ihtiyacını destekleyemediği, oyun alanların çocukların kesintisiz oyun oynamaya elverişli olmadığı ve materyallerin gelişi güzel yerleştirildiği sonuçlarına ulaşılmıştır. Kaçan, Halmatov ve Kartaltepe'nin (2017) yapmış olduğu araştırmada, dış mekanda bulunan salıncak, kaydırak vb. materyallerin bir çok okulda kullanılamaz durumda olduğu ve farklı yaş gruplarına uygun materyallerin bulunmadığı sonucuna ulaşılmıştır. Benzer şekilde Atabey ve arkadaşlarının (2009) yapmış oldukları araştırmada okul öncesi eğitim kurumlarının dış mekanlarının farklı yaş gruplarına yönelik düzenlenmediği ve materyal yönünden yetersiz olduğu sonucuna ulaşılmıştır. Yaptığımız araştırmada da anaokullarının dış mekan olarak bir çok alanda yeterli olmadıkları ortaya konulmuş ve çocukların bütün gelişim alanlarının desteklenebilmesi için uygun hale getirilmesi gerektiği görülmüştür.

\section{Sonuç ve Öneriler}

Eskişehir'deki okul öncesi eğitim kurumlarının dış mekan özelliklerini ortaya koymak ve var olan materyalleri belirlemek amacıyla 15 özel anaokulu ve 20 devlet anaokullarında gözlemler yapılmıştır. Elde edilen gözlemler sonucunda bulgular değerlendirilmiş ve ilgili araştırma soruları altında verilmiştir. Devlet anaokullarındaki oranların özel anaokullarına göre daha yüksek düzeyde olduğu görülmektedir. Özel anaokullarının ise gerek var olan materyaller gerekse dış mekanın özellikleri açısından oranların yetersiz olduğu görülmektedir.

Özel ve devlet anaokulunda var olan materyaller incelendiğinde özel anaokullarında oyun alanı açısından; en fazla var olan materyallerin kaydırak (\%93), salıncak (\%80) olduğu, devlet anaokulunda bu materyallere ek olarak tahterevallinin (\%80) olduğu gözlenmiştir. En az bulunan materyaller arasında ise hayvan besleme alanı açısından; devlet 
anaokullarında kaplumbağa $(\% 0)$ ve tavşan $(\% 0)$ olduğu, özel anaokullarında ise hayvanlara ek olarak ördek $(\% 0)$ ve köpeğin $(\% 0)$ olduğu görülmüştür. Bir diğer alt boyut olan genel görünüm açısından ise; duvarlarda renk kullanımının her iki okulda da \%50'nin üzerinde olduğu görülmüştür.

Devlet ve özel anaokullarındaki dış mekan özellikleri uygunluk düzeyine göre değerlendirildiğinde en fazla uygunluk düzeyi oranlarına devlet anaokullarının sahip olduğu görülmüştür. Dış mekanın büyüklüğü incelendiğinde devlet anaokullarında \%85 oranında daha fazla alana sahip oldukları belirlenmiştir. Doğal yaşam ortamlarını gözlemleyebilme maddesinin uygunluk düzeyi (\%25) ise diğer maddelere oranla en düşük düzeyde görülmüştür. Bu durumda devlet anaokullarının farklı alanlar oluşturma yönünde daha avantajIı oldukları sonucuna ulaşılmıştır. Dış mekan özellikleri uygunluk düzeyi özel okullar açısından incelendiğinde materyallerin dikkat çekiciliği maddesi (\%40) dışında diğer maddeler üzerinden düşük oranda uygunluk düzeyine sahip olduğu belirlenmiştir. Ayrıca su alanı ve özel yetersizliği olan çocuklar için uyarlama açısından bakıldığında özel okulların \%0 ile uygun olmadığı görülmüştür. Bu durumda özel anaokullarının dezavantajlı oldukları söylenebilir. Sonuç olarak; Eskişehir Tepebaşı ve Odunpazarı merkez ilçelerindeki devlet ve özel anaokullarının dış mekanlarının materyal ve uygulama özellikleri açılarından düzenlenmeye ve iyileştirilmeye ihtiyaçları bulunduğu söylenebilmektedir.

Okul öncesi eğitim kurumlarında çocukların bütün gelişim alanlarının desteklenmesi hedef alınarak dış mekan açısından aşağıda bazı önerilerde bulunulmuştur:

- Okul öncesi eğitim kurumlarında çocukların rahat ve özgür hareket edebilmelerini sağlayacak yeterli büyüklükte oyun alanlarının oluşturulması,

- Farklı materyal örnekleri sunularak zengin bir öğrenme çevresinin oluşturulması,

- Çocukların keşfetmesini, yaparak yaşayarak öğrenmesini ve bu doğrultuda araştırma yapmasına imkan sağlayacak, bitki, hayvan ve su gibi doğal yaşam ortamlarının dış mekan içerisinde oluşturulması,

- Dış mekan düzenlemesinin çocukların ilgilerini çekecek ve hayal gücünü harekete geçirecek şekilde renk ve görsellerle desteklenmesi,

- Çocukların günlük yaşantılarında da sıklıkla karşılaştıkları doğal materyalleri, dış mekanda kullanmalarına imkan sağlanması önerilmektedir.

\section{Kaynaklar}

Akçay, D. ve Erkal, S. (2012). Ankara'da farklı semtlerdeki okul öncesi eğitim kurumları iç ve dış mekanlarının kaza riski açısından değerlendirilmesi. Sağlık ve Toplum, 22(2), 36-47.

Aksu, Ö. ve Demirel, Ö. (2011). Trabzon kenti ilköğretim okul bahçelerinde tasarım ve alan kullanımları. Süleyman Demirel Üniversitesi Orman Fakültesi Dergisi, 12(1), 40-46.

Alat, Z., Akgümüş, Ö., ve Cavalı, D. (2012). Okul öncesi eğitimde açık hava etkinliklerine yönelik öğretmen görüş ve uygulamaları. Mersin Üniversitesi Eğitim Fakültesi Dergisi, 8(3), 47-62. 
Atabey, D., Yurt. Ö. ve Ömeroğlu, E. (2009). Okul öncesi eğitim kurumları açık hava oyun alanlarının incelenmesi. Uluslararası 5. Balkan Eğitim ve Bilim Kongresi, 651-653, Edirne.

Baran, M., Yılmaz, A., ve Yıldırım, M. (2007). Okul öncesi eğitimin önemi ve okul öncesi eğitim yapılarındaki kullanıcı gereksinimleri. D.Ü. Ziya Gökalp Eğitim Fakültesi Dergisi, (8) 27-44.

Bay, D. N. (2016). Outdoors in Preschool Teaching: A Model Implementation in Turkey. Journal of Studies in Education, 6(1), 56-73.

Benliay, A., Cüce, B., ve Soydan, O. (2014). Okul öncesi eğitim kurumlarında dış mekan peyzaj tasarımının 5-6 yaş çocuk grubu algısı üzerindeki etkisi. Niğde Üniversitesi Mühendislik Bilimleri Dergisi, 3(1), 37-47.

Brynjegard, S. (2001). Schoolgardens: Raising environmental awareness in children. San Rafael, CA: School of Education, Dominican University of California.

Büyüköztürk, Ş., Çakmak, H., Akgün, Ö., Karadeniz, Ş., ve Demirel, F. (2017). Bilimsel araştırma yöntemleri. Ankara: Pegem.

Çelik, A. (2012). Okul öncesi eğitim kurumlarında açık alan kullanımı: Kocaeli örneği. Atatürk Üniversitesi Ziraat Fakültesi Dergisi, 43(1), 79-88.

Çukur, D. (2011). Okul öncesi çocukluk döneminde sağlıklı gelişimi destekleyici dış mekan tasarımı. SDÜ Orman Fakültesi Dergisi, 12(1), 70-76.

Demiriz, S., Karadağ, A., ve Ulutaş, í. (2011). Okul öncesi eğitim kurumlarında eğitim ortamı ve donanım (2. Baskı). Ankara: Anı Yayınclık.

Duman, G., Koçak, N. (2013). Çocuk oyun alanlarının biçimsel özellikleri açısından değerlendirilmesin (Konya Illi Örneği). Türk Eğitim Bilimleri Dergisi. 11(1), 64-81.

Erdönmez, M. (2007). İlköğretim okulu bahçelerinde peyzaj tasarım normları. İstanbul Üniversitesi Orman Fakültesi Dergisi, 1(57), 106-122.

Fazlıoğlu, Y. (2012). Erken çocukluk gelişimi ve eğitimi. İstanbul: Paradigma Kitapevi Yayınları.

Francis, C. (1998). Child care outdoor spaces. C. C. Marcus ve C. Francis (Eds.), People places: design guidelines for urban open space (2. Baskı.) (ss. 259-310). New York: John Wiley \& Sons.

Fjortoft, I. \& J. Sageie (2000). The Natural environment as a playground for children: Landscape description and analyses of a natural landscape. Landscape and Urban Planning 48(1/2), 8397. 
Gömleksiz, M., Demir, Ö., Kilimci, S., Koçoğlu Meek, Ç., Akar Vural, R., ve Erdal, E. (2008). School yards under the Magnifying Glass: A Qualitative Studying Violence and Childrens' Rights, ilköğretim Online, 7(2), 273- 287.

Gül, A. ve Küçük V. (2001). Kentsel açık-yeşil alanlar ve Isparta kenti örneğinde irdelenmesi Süleyman Demirel Üniversitesi Orman Fakültesi Dergisi,2, 27-48.

Gül, E.D. (2012). Ailelerin çocuk bahçelerine ve çocuk bahçelerindeki materyallere bakış açılarının incelenmesi. Çukurova Üniversitesi Sosyal Bilimler Enstitüsü Dergisi, 21(3), 261-274.

Gülay, H. ve Ekici, G. (2010). MEB Okul öncesi eğitim programının çevre eğitimi açısından analizi. Türk Fen Eğitimi Dergisi,7(1),74,84.

Güleş, F. (2013). Okul öncesi eğitimde fiziksel çevreye ilişkin kalite standartlarının belirlenmesi. Yayınlanmamış Doktora Tezi, Selçuk Üniversitesi Sosyal Bilimler Enstitüsü, Konya.

Güleş, F. ve Erişen, Y. (2013). Okul öncesi eğitimde fiziksel çevre standartlarını belirleme: Paydaş görüşlerine dayalı bir analiz. Selçuk Üniversitesi Sosyal Bilimler Enstitüsü Dergisi, 30, 129-138.

Hepcan, Ş., Kaplan, A., Küçükerbaş, E., ve Özkan, B (2001). Kemalpaşa (İzmir) Kentsel dış mekanlarının yeterliliği üzerine bir araştırma. Kemalpaşa (İzmir). Ege Üniversitesi Ziraat Fakültesi Dergisi, 38(2-3), 143-150.

Johnson, J.M. (2000). Design for learning: Values, qualities and processes of enriching school landscapes. [11/09/18]. http://www.asla.org/latis1/LATIS-cover.htm.

Kaçan, M., Halmatov, M., ve Kartaltepe, O. (2017). Okul öncesi eğitim kurumları bahçelerinin incelenmesi. Erken Çocukluk Çalışmaları Dergisi, 1(1), 60-70.

Kalburan, N. (2014). Denizli ilinde bulunan resmi ve özel anaokulu bahçelerinin karşılaştırılmalı olarak incelenmesi. Pamukkale Üniversitesi Sosyal Bilimler Enstitüsü Dergisi, 18, 99-113.

Karaburun, A., Demirci, A., ve Saka, E. (2015). İstanbul Avrupa yakasındaki okul bahçelerinin öğrenci sayısına göre yeterliliklerinin mekansal olarak değerlendirilmesi. Marmara Coğrafya Dergisi. 31, 20-47.

Karadağ, A., Mutlu, S., ve Sayın, Ş. (2012). Okul bahçelerinin oyun alanı olarak değeri: Düzce kenti örneği. Ormanclık Dergisi, 8(2), 45-46.

Karakaya, B. ve Kiper, T. (2013). Edirne kent merkezindeki bazı ilköğretim okul bahçelerinin peyzaj tasarım ilkeleri açısından mevcut durumunun belirlenmesi Tekirdağ Ziraat Fakültesi Dergisi,10(1), 59-71.

Karaküçük, S. (2008). Okul öncesi eğitim kurumlarında fiziksel/mekansal koşulların incelenmesi: Sivas ili örneği. C.Ü. Sosyal Bilimler Dergisi, 32(2), 307-320. 
Karamustafaoğlu, S. ve Kandaz, U. (2006). Okul öncesi eğitimde fen etkinliklerinde kullanılan öğretim yöntemleri ve karşılaşılan güçlükler. Gazi Eğitim Fakültesi Dergisi,26(1), 65-81.

Karataç, T., Kartal, S., ve Kocabaş, í. (2016). Bağımsız anaokullarının fiziki alanlarının yönetimi. International Journal of Field Education, 2(2), 1-19.

Karatekin, K. ve Çetinkaya, G. (2013). Okul bahçelerinin çevre eğitimi açısından değerlendirilmesi. Manisa ili örneği. Ulusararası Sosyal Araştırmalar Dergisi, 27(6), 1307-9581.

Kaymaz, M. (2015). Eğitim yapılarında bedensel engellilere yönelik "engelsiz tasarım". 3. Ulusal Mobilya Kongresi, 238-250, Konya.

Kesicioğlu, O., Alisinanoğlu, F. (2009). 60- 72 aylık çocukların çevreye karşı tutumlarının çeşitli değişkenler açısından incelenmesi. Ahi Evran Üniversitesi Eğitim Fakültesi Dergisi. 10(3), 37-48.

Kubanç, Y. (2014). Okul öncesi eğitim kurumlarının fiziki durumunun incelenmesi. Uluslararası Sosyal Araştırmalar Dergisi, 7(31), 675-678.

Malone, K., \& Tranter, P. (2003). "Children's environmental learning and the use, design and management of schoolgrounds. Children Youth and Environments, 13(2), 87-137.

Merriam, S.B. (2013). Nitel araştırma: Desen ve uygulama için bir rehber. S. Turan (Çev. Ed.). Ankara: Nobel Yayıncllık.

MEB. (2013). Erken çocukluk eğitim kurumlarında fiziksel özellikler ve personel. Ankara: Milli Eğitim Bakanlığı Yayınları.

Miles, M. \& Huberman, M. (1994). An expanded sourcebook qualitative data analysis. London: Sage.

Muhacir, E. ve Özalp, A. (2011). Artvin kenti ilköğretim okul bahçelerinin nitelik ve niceliksel durumlarının coğrafi bilgi sistemleri kullanılarak belirlenmesi. Artvin Çoruh Üniversitesi Orman Fakültesi Dergisi, 12(2), 172-184.

Ömeroğlu, E. (2005). Okul öncesi dönemde eğitim ortamlarının düzenlenmesi. Ş. Yaşar (Ed.), Okul öncesi eğitimin ilke ve yöntemleri (ss. 59-70). Eskişehir: Anadolu Üniversitesi Yayınları.

Öztürk, A. ve Bayraktar, D. (2017). Anaokullarındaki doğal mekan ve materyallerin çocuk gelişimindeki yeri. Karadeniz Teknik Üniversitesi, 12(1), 25-35.

Özkubat, S. (2013). Okul öncesi kurumlarında eğitim ortamlarının düzenlenmesi ve donanım. Adnan Menderes Üniversitesi Eğitim Bilimleri Dergisi, 4(2), 58-66.

Pardee, M., Gillman, A. ve Larson, C. (2005). Community investment collaborative for kids: resource guide 4. USA: The Local Initiatives Support Corporation/Community Investment Collaborative for Kids. 
Ramazan, O. (2007). Okul öncesi kurumlarda fiziksel ortam. A. Oktay ve Ö. Polat Unutkan (Ed.), Okul öncesi eğitimde güncel konular. İstanbul: Morpa.

Sağlık, A., Sağlık, E., ve Kelkit, A. (2015). Çanakkale barbaros günışı̆̆ı anaokulu peyzaj projesi. Hasan Kalyoncu Üniversitesi, Güzel Sanatlar ve Mimarlık Fakültesi, 3(1), 39-47.

Şişman, E. ve Özyavuz, M. (2010). Çocuk oyun alanlarının dağılımı ve kullanım yeterliliği: Tekirdağ örneği. Tekirdağ Ziraat Fakültesi Dergisi,7(1), 13-22.

Ummanel, A. (2017). Kum ve oyun alanları üzerine bir inceleme. Abant Izzet Baysal Üniversitesi Eğitim Fakültesi Dergisi, 17(3), 1539-1566.

Uslu, A. \& Shakouri, N. (2012). Engelli çocuklara dost oyun alanı ve dış mekan tasarımı. Erciyes Üniversitesi Fen Bilimleri Enstitüsü Dergisi, 28(5), 367-374.

Vural, H. ve Sevgi, Y. (2016). İyileştirilmiş fiziksel çevre şartlarının öğrencilerinin gelişimine etkisinin öğretmen gözüyle değerlendirilmesi. Bayburt Eğitim Fakültesi Dergisi, 11(2), 518-535.

White, R. \& V. Stoecklin . (1998). Children's outdoor play and learning environments: Returning to nature . [09/09/18]. http://www.whitehutchinson.com/children/articles/outdoor.shtml.

Yılmaz, A. (1995). Erzurum kenti okul bahçelerinin peyzaj mimarlı̆̆ ilkeleri yönünden incelenmesi. Atatürk Üniversitesi Ziraat Fakültesi Dergisi, 26(4), 437-547. 
Fatma GENEY | Zeynep ÖZSOY | Döndü Neslihan BAY

\section{EK: Özel ve Devlet Anaokullarının Listesi}

\begin{tabular}{|c|c|c|}
\hline & Devlet Anaokulları & Özel Anaokulları \\
\hline 1 & Adnan Menderes Anaokulu & Özel Beyaz Zambak Anaokulu \\
\hline 2 & Seçil Akkurt Anaokulu & Özel Yumurcak Anaokulu \\
\hline 3 & Yunuskent Anaokulu & Özel Neşe Erberk Anaokulu \\
\hline 4 & Zehra Sarar Anaokulu & Altın Çocuklar Akademisi \\
\hline 5 & Vali Mehmet Kılıçlar Anaokulu & Özel Eskişehir Küçük Şeyler Anaokulu \\
\hline 6 & Lamia Dayanç Anaokulu & Özel Ailem Anaokulları \\
\hline 7 & Nermin Özdemir Anaokulu & Özel Paylaşım Anaokulu \\
\hline 8 & Avukat Mail Büyükerman Anaokulu & Özel Çocuk Kulübü Anaokuları \\
\hline 9 & Sakarya Anaokulu & Özel Yeni Yol Anaokulu \\
\hline 10 & Cemalettin Gökay Anaokulu & Özel Birdir Bir Anaokulu \\
\hline 11 & Öğretmen Esra Akkaya Anaokulu & Özel Fidanlar Anaokulu \\
\hline 12 & Eczacı Faruk Erden Anaokulu & Özel Helen Doron Anaokulu \\
\hline 13 & Kutlu Doğum Anaokulu & Özel Çocuk Akademisi \\
\hline 14 & Zübeyde Hanım Anaokulu & Özel Kır Çiçekleri Anaokulu \\
\hline 15 & Vilayetler Hizmet Götürme Birliği Anaokulu & Özel Bahar Çocuk Anaokulu \\
\hline
\end{tabular}


Eskişehir Osmangazi Üniversitesi Sosyal Bilimler Dergisi

\begin{tabular}{|l|l|l|}
\hline 16 & Toki Söğütönü Anaokulu & \\
\hline 17 & Cemal Ererdi Anaokulu & \\
\hline 18 & Muttalip Anaokulu & \\
\hline 19 & Kutipoğlu Anaokulu & \\
\hline 20 & Hayme Hatun Anaokulu & \\
\hline
\end{tabular}

